\title{
The Neuroprotective Effects of Brazilian Green Propolis on Neurodegenerative Damage in Human Neuronal SH-SY5Y Cells
}

\author{
Junjun Ni, ${ }^{1}$ Zhou Wu, ${ }^{1,2}$ Jie Meng, ${ }^{1}$ Aiqin Zhu, ${ }^{3}$ Xin Zhong, \\ Shizheng $\mathrm{Wu}^{3}{ }^{3}$ and Hiroshi Nakanishi ${ }^{1}$ \\ ${ }^{1}$ Department of Aging Science and Pharmacology, Faculty of Dental Science, Kyushu University, Fukuoka 812-8582, Japan \\ ${ }^{2}$ OBT Research Center, Faculty of Dental Science, Kyushu University, Fukuoka 812-8582, Japan \\ ${ }^{3}$ Institute of Geriatrics, Qinghai Provincial Hospital, Xining 810007, China \\ Correspondence should be addressed to Zhou Wu; zhouw@dent.kyushu-u.ac.jp
}

Received 4 July 2016; Revised 19 December 2016; Accepted 28 December 2016; Published 6 February 2017

Academic Editor: Byoung-Joon Song

Copyright (C) 2017 Junjun Ni et al. This is an open access article distributed under the Creative Commons Attribution License, which permits unrestricted use, distribution, and reproduction in any medium, provided the original work is properly cited.

\begin{abstract}
Oxidative stress and synapse dysfunction are the major neurodegenerative damage correlated to cognitive impairment in Alzheimer's disease (AD). We have found that Brazilian green propolis (propolis) improves the cognitive functions of mild cognitive impairment patients living at high altitude; however, mechanism underlying the effects of propolis is unknown. In the present study, we investigated the effects of propolis on oxidative stress, expression of brain-derived neurotrophic factor (BDNF), and activity-regulated cytoskeleton-associated protein (Arc), the critical factors of synapse efficacy, using human neuroblastoma SHSY5Y cells. Pretreatment with propolis significantly ameliorated the hydrogen peroxide- $\left(\mathrm{H}_{2} \mathrm{O}_{2}\right.$-) induced cytotoxicity in SH-SY5Y cells. Furthermore, propolis significantly reduced the $\mathrm{H}_{2} \mathrm{O}_{2}$-generated reactive oxygen species (ROS) derived from mitochondria and 8-oxo- $2^{\prime}$-deoxyguanosine (8-oxo-dG, the DNA oxidative damage marker) but significantly reversed the fibrillar $\beta$-amyloid and IL-1 $\beta$-impaired BDNF-induced Arc expression in SH-SY5Y cells. Furthermore, propolis significantly upregulated BDNF mRNA expression in time- and dose-dependent manners. In addition, propolis induced Arc mRNA and protein expression via phosphoinositide-3 kinase (PI3K). These observations strongly suggest that propolis protects from the neurodegenerative damage in neurons through the properties of various antioxidants. The present study provides a potential molecular mechanism of Brazilian green propolis in prevention of cognitive impairment in $\mathrm{AD}$ as well as aging.
\end{abstract}

\section{Introduction}

Alzheimer's disease (AD) is the most common form of dementia in aging societies worldwide [1] and the number of $\mathrm{AD}$ is growing dramatically [2]. Oxidative stress is a major component of the harmful cascades activated in the development of aging-related neurodegenerative disorders, including $\mathrm{AD}[3,4]$, because the overproduction of reactive oxygen species (ROS) causes cell damage through the promotion of lipid peroxidation, DNA damage, and the regulation of death proteins [5]. Antioxidant therapy therefore is considered as an approach in prevention and clinical management of $\mathrm{AD}$ [6]. On the other hand, dysfunction of hippocampal synaptic efficacy is known to be related to cognitive impairment in $\mathrm{AD}[7,8]$ as well as in aging [9-11], and synaptic efficacy has protective effects against $\mathrm{AD}[12,13]$.
Activity-regulated cytoskeleton-associated protein (Arc) is a critical immediate-early gene that has been implicated in generated stable changes in synaptic efficacy $[14,15]$, as suppression of Arc expression impairs the synaptic plasticity and memory consolidation $[11,14,16]$. As a member of the neurotrophin family, brain-derived neurotrophic factor (BDNF) plays a fundamental role in the synaptic efficacy by inducing Arc expression [17, 18], and BDNF-induced Arc expression contributes to cognitive functions $[14,19,20]$. Indeed, fibrillar $\beta$-amyloid, the main component of plaques in the brains of $\mathrm{AD}$ patients, has been shown to impair the BDNF-induced Arc expression in the cultured cortical neurons, even at low levels [21]; therefore, interfering with BDNF signaling affects the downstream neuronal functions that contribute to the development of AD [22]. However, mounting evidence 
suggests that neuroinflammation, induced by proinflammatory cytokines, increases the risk of cognitive impairment [23-25]. As a potent activator for exacerbating neuroinflammation, interleukin-1 $\beta$ (IL-1 $\beta$ ) has been shown to mediate synaptic efficacy by suppressing BDNF-induced Arc expression [26].

Propolis is a resinous substance produced by honeybees as a defense against intruders. It has relevant therapeutic properties that have been used since ancient times. The chemical composition of propolis depends on the local floral at the site of collection $[27,28]$. The neuroprotective effects of propolis and its active components, such as baccharin, $\mathrm{p}$ Coumaric acid, and Artepillin C, have been established [2932]. In addition, Artepillin C, a major component of Brazilian propolis, has been shown to act as a neurotrophic-like factor for promoting neuron growth factor- (NGF-) induced neurite outgrowth [33]. Our ongoing human research at high altitude has shown that elderly individuals treated with propolis score significantly higher on cognitive tests than nontreated subjects (Zhu and Wu unpublished data), and we hypothesized that propolis may have neuroprotective effects on neurons directly. However, we recently found that propolis protects against the hypoxia-induced microglia mediated neuroinflammation $[34,35]$. In the present study, we focused on the effects of propolis on the hydrogen peroxide- $\left(\mathrm{H}_{2} \mathrm{O}_{2}\right.$ ) induced oxidative stress, and expression of BDNF and Arc using cultured human neuroblastoma SH-SY5Y cells, which are widely used for the study of neurodegenerative damage in vitro [36].

\section{Material and Methods}

2.1. Reagents. Brazilian green propolis ethanol extract (propolis) was purchased from Yamada Apiculture Center, Inc. (Okayama, Japan). Minimal essential medium (MEM), F12, fetal bovine serum (FBS), penicillin-streptomycin. and Hoechst 33342 were purchased from Thermo Fisher Scientific (Waltham, MA, USA). $\mathrm{H}_{2} \mathrm{O}_{2}$ (30\%), GF 109203X hydrochloride (protein kinase $\mathrm{C}$ inhibitor), and ANA-12 (TrkB selective antagonist) were purchased from Selleckchem (Houston, TX, USA). Bayl1-7082 (a specific NF- $\kappa$ B inhibitor), U0126 (ERK inhibitors), Carbachol, and human BDNF were purchased from Sigma-Aldrich Inc. (St. Louis, MO, USA). Y-27632 dihydrochloride (Rho-associated protein kinase inhibitor) was purchased from TOCRIS (Avonmouth, Bristol, UK). Wortmannin (phosphoinositide 3-kinase inhibitor) was purchased from Millipore (California, USA). Artepillin C was purchased from WAKO (Osaka, Japan). RNAiso Plus was purchased from Takara (Hoto-ku, Osaka, Japan). QuantiTect Reverse Transcription Kit and Rotor-Gene SYBR Green RT-PCR Kit were purchased from Qiagen (Hilden, Germany). A Cell-Counting Kit (CCK-8) was purchased from Dojindo (Kumamoto, Japan). Human recombinant IL-1 $\beta$ was purchased from R\&D (Minneapolis, USA). $\beta$-Amyloid (1-42) was purchased from ANASPEC (California, USA), dissolved in endotoxin-free sterile water and incubated at $37^{\circ} \mathrm{C}$ for $24 \mathrm{~h}$ to induce the fibril formation.

2.2. SH-SY5Y Cell Culture. Human neuroblastoma SH-SY5Y cells purchased from American Type Culture Collection
(Manassas, VA, USA) were maintained in a complete growth medium (MEM/F-12 mixture containing 10\% fetal bovine serum, supplemented with $\mathrm{NaHCO}_{3}$ and $100 \mathrm{U} / \mathrm{mL}$ penicillin-streptomycin). The cells were cultured at $37^{\circ} \mathrm{C}$ in a $5 \% \mathrm{CO}_{2}$ humidified incubator.

2.3. Cell Viability Assay. SH-SY5Y cells were seeded in 96well plates $\left(5 \times 10^{3}\right.$ cells/well $)$ overnight. After treatment with propolis, $\mathrm{fA} \beta$, and IL- $1 \beta$, a cell viability assay was performed using a Cell-Counting Kit (Dojindo) in accordance with the previously described method [34]. The optical density was read at a wavelength of $450 \mathrm{~nm}$ with a microplate reader. The cell viability was calculated by dividing the optical density of the treated group by that of the control group.

2.4. Observations of Morphological Changes. The cells were seeded in 6 -well plates $\left(2 \times 10^{5}\right.$ cells $\left./ \mathrm{mL}\right)$ for $24 \mathrm{~h}$ and then treated with $\mathrm{H}_{2} \mathrm{O}_{2}$ at a concentration of $100 \mu \mathrm{M}$ for $24 \mathrm{~h}$ with or without propolis (methanol extraction). The cellular morphology was observed and photographed using a brightfield microscope (Nikon, ECLIPSE Ti-S, Japan).

2.5. Detection of Mitochondrial ROS. Mitochondrial ROS were measured using MitoSOX ${ }^{\mathrm{TM}}$ Red (Invitrogen, USA), which is a live-cell permeant that rapidly and selectively targets mitochondria [37]. Once in the mitochondria, MitoSOX Red reagent is oxidized by superoxide and exhibits red fluorescence (with excitation at $510 \mathrm{~nm}$ and emission at $580 \mathrm{~nm}$ ). The cultured SH-SY5Y cells were seeded in 24-well plates (2 $\times 10^{5}$ cells $/ \mathrm{mL}$ ) and incubated with or without propolis for $1 \mathrm{~h}$ (methanol extraction, $10 \mu \mathrm{g} / \mathrm{mL}$ ). The cells were then further exposed to $\mathrm{H}_{2} \mathrm{O}_{2}(100 \mu \mathrm{M})$ for $1 \mathrm{~h}$. After incubation in Hank's balanced salt solution (HBSS) containing $5 \mathrm{mM}$ MitoSOX Red for $10 \mathrm{~min}$ at $37^{\circ} \mathrm{C}$, the cells were washed twice with PBS and then mounted in a warm buffer for imaging. Images were collected using a fluorescence microscope (Nikon, ECLIPSE Ti-S, Japan).

2.6. Immunofluorescence Imaging. Immunofluorescence imaging was performed as described previously [34, 38]. SHSY5Y cells were seeded in 24 -well plates $\left(2 \times 10^{5}\right.$ cells $\left./ \mathrm{mL}\right)$ for $24 \mathrm{~h}$ and then treated with $\mathrm{H}_{2} \mathrm{O}_{2}(100 \mu \mathrm{M})$ for $4 \mathrm{~h}$, with or without pretreatment with propolis (methanol extraction, $10 \mu \mathrm{g} / \mathrm{mL}$ ) for $1 \mathrm{~h}$, and fixed with $4 \%$ paraformaldehyde. After washing the cells with PBS twice, they were incubated with mouse anti-8-oxo-dG $(1: 500)$ overnight at $4^{\circ} \mathrm{C}$ and then incubated with anti-mouse Alexa 488 (1:2000, Jackson Immunoresearch Lab. Inc.) at $4^{\circ} \mathrm{C}$ for $2 \mathrm{~h}$. After washing by PBS, the nucleus was stained by Hoechst 33342. The cells were mounted in the antifading medium, Vecta shield, and the fluorescence images were taken using a confocal laser scanning microscope (CLSM; C2si, Nikon, Japan).

2.7. Real-Time Quantitative Polymerase Chain Reaction ( $q R T$ $P C R$ ). The mRNA isolated from the SH-SY5Y cells at various time points were subjected to a real-time qRT-PCR. The total RNA was extracted using the RNAiso Plus in accordance with the manufacturer's instructions. A total of $800 \mathrm{ng}$ of extracted RNA was reverse transcribed to cDNA 
using the QuantiTect Reverse Transcription Kit. After an initial denaturation step at $95^{\circ} \mathrm{C}$ for $5 \mathrm{~min}$, temperature cycling was initiated. Each cycle consisted of denaturation at $95^{\circ} \mathrm{C}$ for $5 \mathrm{~s}$, annealing at $60^{\circ} \mathrm{C}$ for $10 \mathrm{~s}$, and elongation for $30 \mathrm{~s}$. In total, 40 cycles were performed. The cDNA was amplified in duplicate using a Rotor-Gene SYBR Green RTPCR Kit with a Corbett Rotor-Gene RG-3000A Real-Time PCR System (Sydney, Australia). The data were evaluated using the RG-3000A software program (version Rotor-Gene 6.1.93, Corbett). The sequences of primer pairs were as follows: Arc, $5^{\prime}$-CCACCTGCTTGGACACCTC- $3^{\prime}$ and $5^{\prime}-$ CCGCCCCGAGGAGTTTG-3'; BDNF, $5^{\prime}$-GGATGAGGACCAGAAAGT- $3^{\prime}$ and $5^{\prime}$-AGCAGAAAGAGAAGAGGAG$3^{\prime}$; actin, $5^{\prime}$-AGAGCTACGAGCTGCCTGAC- $3^{\prime}$ and $5^{\prime}-$ AGCACTGTGTTGGCGTACAG-3'.

For data normalization, an endogenous control (actin) was assessed to control for the cDNA input, and the relative units were calculated by a comparative Ct method. All of the real-time qRT-PCR experiments were repeated three times, and the results are presented as the means of the ratios \pm standard error of the mean.

2.8. Electrophoresis and Immunoblotting. SH-SY5Y cells were cultured at a density of $2 \times 10^{5}$ cells $/ \mathrm{mL}$. Cells were harvested at each time point with various stimulations, and immunoblotting analyses were conducted. Briefly, each specimen was electrophoresed using 12\% SDS-polyacrylamide gels. The proteins on the SDS gels were then electrophoretically transferred to nitrocellulose membranes. Following blocking, the membranes were incubated at $4^{\circ} \mathrm{C}$ overnight under gentle agitation with each primary antibody: mouse anti-Arc (1:1000; Abcam, Heidelberg, Germany) and mouse anti-actin (1:5000; Abcam). After washing, the membranes were incubated with horseradish peroxidase- (HRP-) labeled anti-mouse (1:2000; GE Healthcare, Buckinghamshire, UK) for $2 \mathrm{~h}$ at room temperature. Subsequently, the membranebound, HRP-labeled antibodies were detected using an enhanced chemiluminescence detection system (ECK lit; GE Healthcare) with an image analyzer (LAS-1000; Fuji Photo Film; Minato-ku, Tokyo, Japan).

2.9. Statistical Analysis. The data are represented as the means \pm standard error of the mean. The statistical analyses were performed by a one- or two-way analysis of variance with a post hoc Tukey's test using the GraphPad Prism software package (GraphPad Software, California, USA). A value of $p<0.05$ was considered to indicate statistical significance.

\section{Results}

3.1. Effect of Propolis on Cell Viability in SH-SY5Y Cells. We first examined the effects of propolis on the viability of SHSY5Y cells using CCK8 assay kit. The mean cell viability was not significantly changed after treatment with the ethanol extracts of propolis at final concentrations between 0.25 and $10 \mu \mathrm{g} / \mathrm{mL}$ for $48 \mathrm{~h}$ (Figure $1(\mathrm{a})$ ). However, the mean cell viability was significantly reduced after pretreatment with propolis at a final concentration of over $25 \mu \mathrm{g} / \mathrm{mL}$ ( $75 \%$ of viable cells). We therefore used methanol extracts of propolis at concentrations up to $10 \mu \mathrm{g} / \mathrm{mL}$ and $\mathrm{H}_{2} \mathrm{O}_{2}$ at $100 \mu \mathrm{M}$ concentration [38] to investigate the effects of propolis on the $\mathrm{H}_{2} \mathrm{O}_{2}$ induced cytotoxicity of SH-SY5Y cells in the subsequent experiments. The $\mathrm{H}_{2} \mathrm{O}_{2}$-induced cell death (79\% of viable cells) was significantly restored by pretreatment with propolis (90\% of viable cells) (Figure 1(b)). Morphological changes observed included the degeneration of $\mathrm{H}_{2} \mathrm{O}_{2}$-treated $\mathrm{SH}$ SY5Y cells, which exhibited the disappearance of the neurites and shrinkage (Figure 1(c)). The percentage of viable cells was also reduced by $\mathrm{H}_{2} \mathrm{O}_{2}$ in a dose-dependent manner (data not shown). It is noted that the neuritis and shrinkage of cells were attenuated by pretreatment with propolis (Figure 1(c)). These observations strongly demonstrate that pretreatment with propolis protects $\mathrm{SH}-\mathrm{SY} 5 \mathrm{Y}$ cells from $\mathrm{H}_{2} \mathrm{O}_{2}$-induced cytotoxicity. Pretreatment with methanol extracts of propolis $(10 \mu \mathrm{g} / \mathrm{mL})$ for $1 \mathrm{~h}$ was set up in the subsequent experiments.

\subsection{Effects of Propolis on the $\mathrm{H}_{2} \mathrm{O}_{2}$-Induced Oxidative Stress} in SH-SY5Y Cells. Oxidative stress is an important inducer of neurotoxicity in $\mathrm{AD}$ patients [39]; following our previous experiments, we used two approaches to address the effects of propolis on $\mathrm{H}_{2} \mathrm{O}_{2}$-induced oxidative stress in $\mathrm{SH}-\mathrm{SY} 5 \mathrm{Y}$ cells: one approach was the use of a MitoSOX Red probe, as a marker for mitochondria-derived ROS generation [35], and the other was immunofluorescence imaging for a biomarker of oxidation-damaged DNA marker, 8-oxo-dG [40]. In comparison to the untreated cells, the expression of MitoSOX Red signals was significantly increased in SH-SY5Y cells after exposure to $\mathrm{H}_{2} \mathrm{O}_{2}$ for $1 \mathrm{~h}$, suggesting that the mitochondria are the early origin of ROS generation during oxidative stress. Pretreatment with propolis significantly inhibited the $\mathrm{H}_{2} \mathrm{O}_{2}$ induced mitochondria-derived ROS generation in SH-SY5Y cells (Figure 2(a)), and the mean fluorescent intensity of MitoSOX Red oxidation was found to significantly increase in comparison to that in the cells that were not exposed to $\mathrm{H}_{2} \mathrm{O}_{2}$ (4.93 versus $1,{ }^{* * *} p<0.001$, Figure $2(\mathrm{~b})$ ). Pretreatment with the propolis methanol extracts for $1 \mathrm{~h}$ significantly reduced the immunofluorescence intensity of MitoSOX Red oxidation in the $\mathrm{H}_{2} \mathrm{O}_{2}$-exposed $\mathrm{SH}$-SY5Y cells (1.8 versus $4.93,{ }^{* * *} p<0.001$, Figure $\left.2(\mathrm{~b})\right)$, thus confirming the antioxidant properties of propolis. Immunofluorescence imaging showed a significant inverse relationship between Hoechst and 8-oxo-dG after exposure of SH-SY5Y cells to $\mathrm{H}_{2} \mathrm{O}_{2}$ for $4 \mathrm{~h}$ (Figure 2(c)), and the mean fluorescent intensity of 8 oxo-dG was found to significantly increase in comparison to that in the cells that were not exposed to $\mathrm{H}_{2} \mathrm{O}_{2}(2.75$ versus $1,{ }^{* * *} p<0.001$, Figure $\left.2(\mathrm{~d})\right)$. It is noted that pretreatment with the propolis for $2 \mathrm{~h}$ significantly reduced the immunofluorescence intensity of 8-oxo-dG in the $\mathrm{H}_{2} \mathrm{O}_{2}$ exposed SH-SY5Y cells (1.36 versus $2.75,{ }^{* * *} p<0.001$, Figure $2(d))$. These observations demonstrate that propolis could attenuate oxidative stress in neuronal cells.

3.3. Effect of Propolis on the Fibrillar A $\beta$-Induced Impairment of BDNF-Induced Arc Expression in SH-SY5Y Cells. Soluble $\mathrm{A} \beta$ is known to interfere with synaptic efficacy, as cognitive decline precedes the formation of $A \beta$ plaques, the hallmark of $\mathrm{AD}$ [41]. We therefore examined the effects of propolis on 


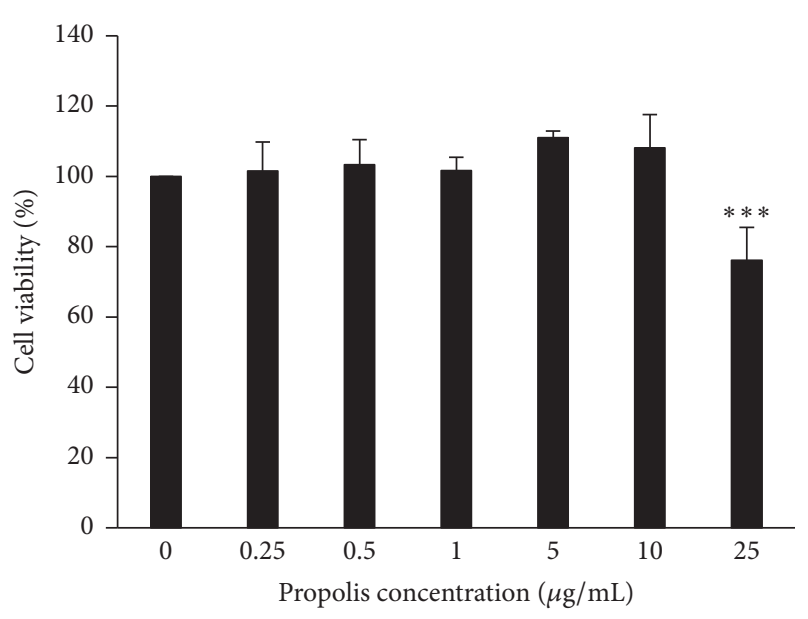

(a)

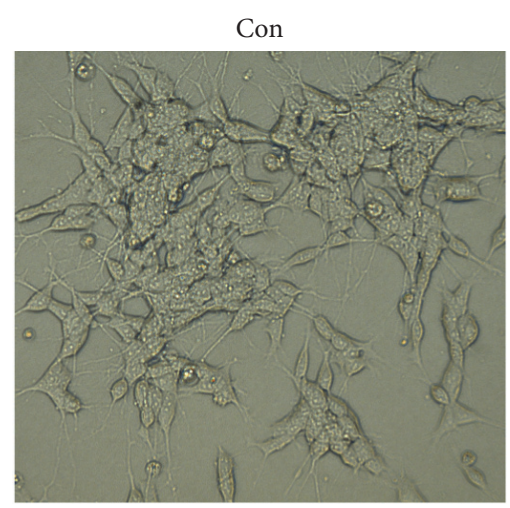

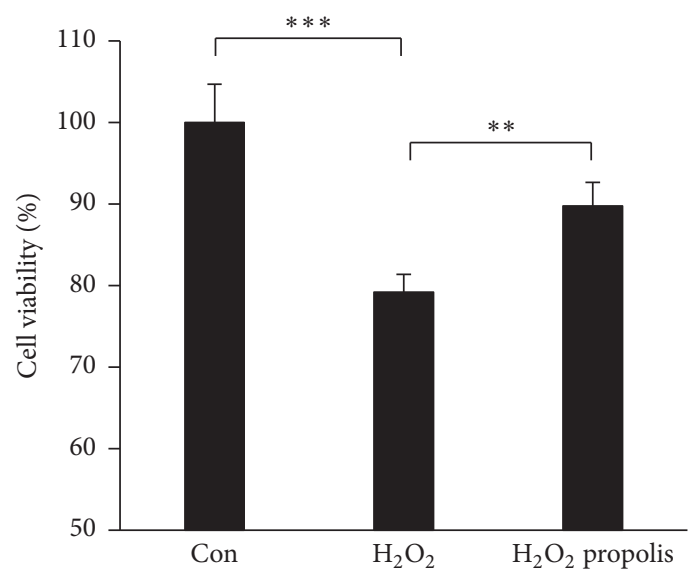

(b)
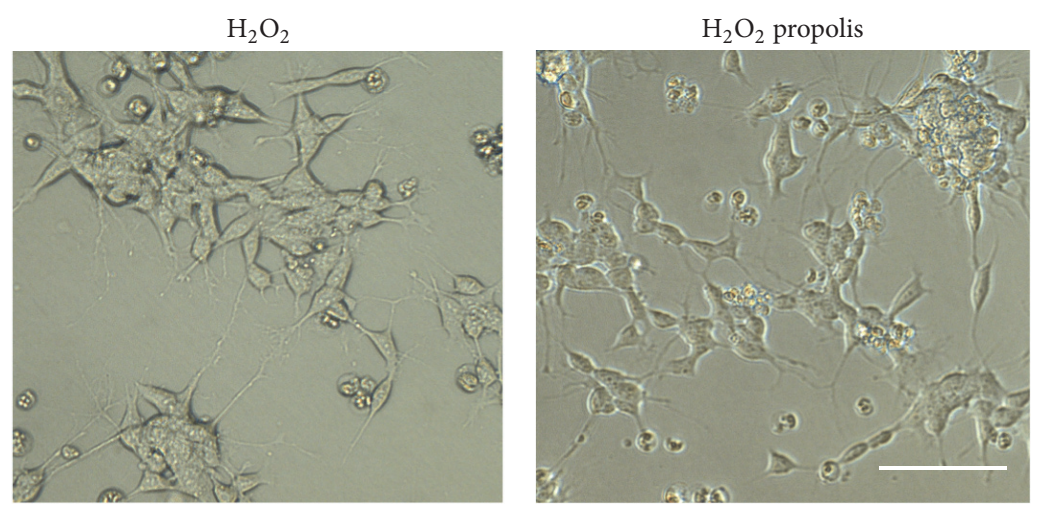

(c)

FIGURE 1: Effects of methanol extracts of propolis on the $\mathrm{H}_{2} \mathrm{O}_{2}$-induced toxicity in SH-SY5Y cells. (a) Cell viability in SH-SY5Y cells pretreatment with different concentrations of propolis for 48 hours. (b) The effect of pretreatment with methanol extracts of propolis for $2 \mathrm{~h}$ on $\mathrm{H}_{2} \mathrm{O}_{2}$ exposed SH-SY5Y cells. Each column and bar represent mean \pm SEM $(n=4$ each $)$. An asterisk indicates a statistically significant difference from the indicated group value $\left({ }^{* *} p<0.01,{ }^{* * *} p<0.001\right)$. (c) The morphological changes of SH-SY5Y cells with or without pretreatment with propolis $(10 \mu \mathrm{g} / \mathrm{mL})$ after expose to $\mathrm{H}_{2} \mathrm{O}_{2}$ for $24 \mathrm{~h}$. Scale bar $=20 \mu \mathrm{m}$.

the impairment of BDNF-induced Arc expression by fA $\beta$ in SH-SY5Y cells, because Arc is the critical factor of synapse efficacy. The mean cell viability was not significantly changed after treatment with $\mathrm{fA} \beta$ at final concentrations between 0.1 and $5 \mu \mathrm{M}$ for $48 \mathrm{~h}$ (Figure $3(\mathrm{a})$ ). However, significant cytotoxicity was observed in cultures treated with fA $\beta$ over $10 \mu \mathrm{M}$ ( $80 \%$ of viable cells). Therefore, $5 \mu \mathrm{M}$ was used as the nonlethal concentration for SH-SY5Y cells in subsequent experiments. Treatment with BDNF $(10 \mathrm{ng} / \mathrm{mL})$ for $120 \mathrm{~min}$ induced 3.5-fold Arc expression in SH-SY5Y cells; however, preexposure to $\mathrm{fA} \beta(5 \mu \mathrm{M})$ for $6 \mathrm{~h}$ suppressed the BDNFinduced Arc expression (Figure 3(b)). Interestingly, this impairment was significantly reversed following treatment with propolis $(10 \mu \mathrm{g} / \mathrm{mL}$ ) for $120 \mathrm{~min}$ (Figure 3(b)). Furthermore, propolis treatment also prevented the $\mathrm{fA} \beta$-induced impairment of BDNF-induced Arc protein expression (Figures 3(c) and 3(d)). These data indicate that propolis reverses the fA $\beta$-induced impairment of BDNF-induced Arc mRNA and protein expression.

3.4. Effect of Propolis on the IL-1 $\beta$-Induced Impairment of BDNF-Induced Arc Expression in SH-SY5Y Cells. As a potent activator for exacerbating neuroinflammation, IL-1 $\beta$ has recently been found to suppress BDNF-dependent synaptic efficacy [26]. We therefore examined the effects of propolis on the IL-1 $\beta$-induced impairment of BDNF-induced Arc expression in SH-SY5Y cells. We first examined the effects of IL- $1 \beta$ on the cell viability to determine the nonlethal concentration of IL- $1 \beta$ on SH-SY5Y cells. The mean cell viability was not significantly changed after treatment with IL-1 $\beta$ at final concentrations between 1 and $500 \mathrm{ng} / \mathrm{mL}$ for $48 \mathrm{~h}$ (Figure 4(a)). However, significant cytotoxicity was observed in cultures treated with IL- $1 \beta$ over $100 \mathrm{ng} / \mathrm{mL}$ ( $90 \%$ of viable cells). We therefore used $20 \mathrm{ng} / \mathrm{mL}$ as the nonlethal concentration for SH-SY5Y cells in subsequent experiments.

Treatment with BDNF $(10 \mathrm{ng} / \mathrm{mL})$ for $120 \mathrm{~min}$ induced 3.4-fold Arc expression in SH-SY5Y cells; however, preexposure to IL-1 $\beta$ ( $20 \mathrm{ng} / \mathrm{mL})$ for $6 \mathrm{~h}$ significantly suppressed the BDNF-induced Arc expression (Figure 4(b)). Interestingly, this impairment was significantly reversed following treatment with propolis $(10 \mathrm{mg} / \mathrm{mL}$ ) for $120 \mathrm{~min}$ (Figure $4(\mathrm{~b}))$. Furthermore, propolis treatment also prevented the IL- $1 \beta$-induced impairment of BDNF-induced Arc protein 


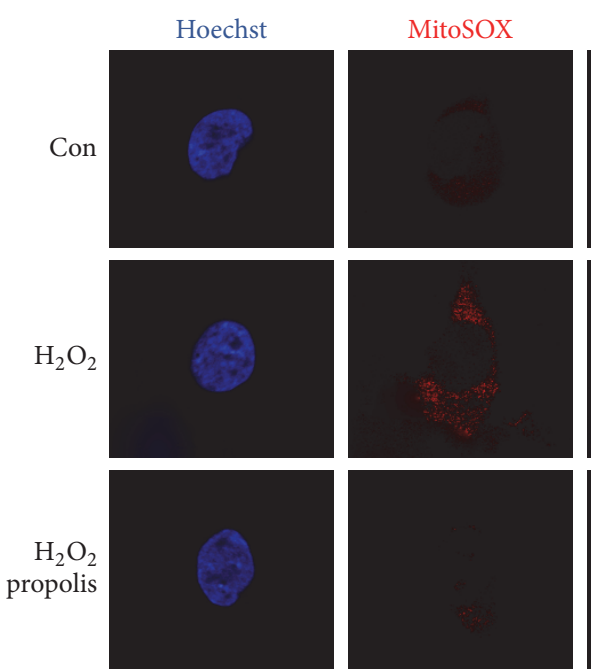

(a)

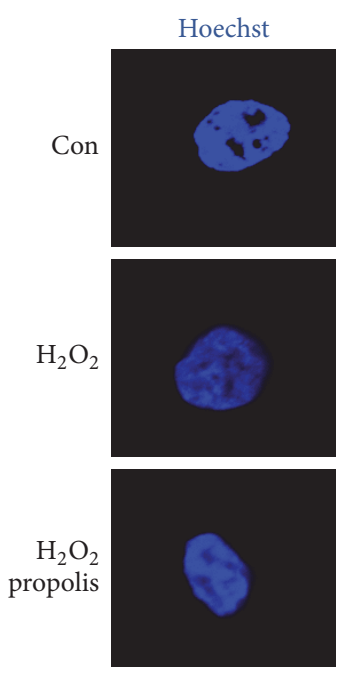

8-oxo-dG
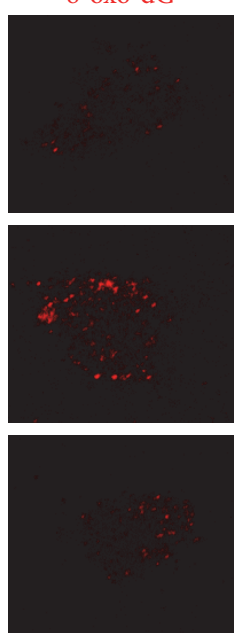

(c)
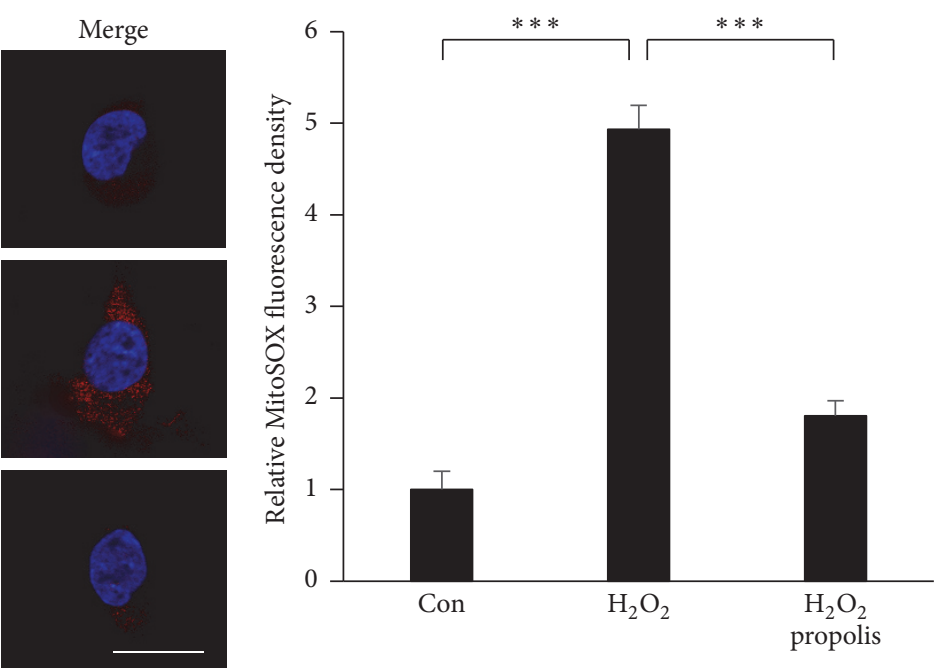

(b)
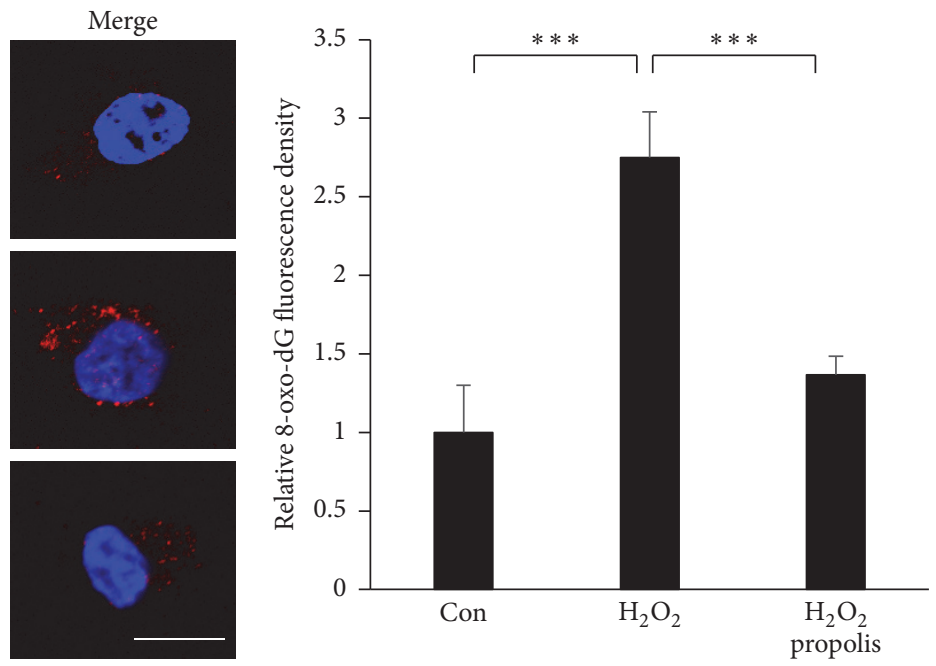

(d)

FIGURE 2: Effects of methanol extracts of propolis on the $\mathrm{H}_{2} \mathrm{O}_{2}$-induced oxidative stress in SH-SY5Y cells. (a) Fluorescent images of MitoSOX Red signals in SH-SY5Y cells exposed to $\mathrm{H}_{2} \mathrm{O}_{2}$ for $1 \mathrm{~h}$ with or without propolis $(10 \mu \mathrm{g} / \mathrm{mL})$ for $2 \mathrm{~h}$. Scale bar $=15 \mu \mathrm{m}$. (b) The quantitative analyses of MitoSOX Red signal intensity in (a). (c) Immunofluorescent CLMS images of 8-oxo-dG (red) with Hoechst-stained nuclei (blue) in SH-SY5Y cells exposed to $100 \mu \mathrm{M}$ of $\mathrm{H}_{2} \mathrm{O}_{2}$ for $4 \mathrm{~h}$ with or without pretreatment with propolis $(10 \mu \mathrm{g} / \mathrm{mL})$ for $2 \mathrm{~h}$. Scale bar $=10 \mu \mathrm{m}$. (d) The quantitative analyses of 8-oxo-dG immunofluorescence signal intensity in (c). The results are expressed as the mean \pm SEM ( $n=4$ each), and the asterisks indicate a statistically significant difference from the indicated group value $\left({ }^{* * *} p<0.001\right)$.

expression (Figures 4(c) and 4(d)). These data indicate that propolis reverses the IL-1 $\beta$-induced impairment of BDNFinduced Arc mRNA and protein expression.

\subsection{Effect of Propolis on BDNF Expression in SH-SY5Y} Cells. We next examined the effects of propolis on BDNF expression in SH-SY5Y cells, because BDNF is the critical neurotrophic factor that is important for synapse efficacy. Pretreatment with propolis significantly increased the BDNF mRNA expression in SH-SY5Y cells from $60 \mathrm{~min}$ up to $240 \mathrm{~min}$, even at a low concentration $(1 \mu \mathrm{g} / \mathrm{mL})$ (Figure 5(a)). Furthermore, treatment with propolis for $60 \mathrm{~min}$ increased the BDNF mRNA expression in SH-SY5Y cells in a dosedependent manner (Figure 5(b)). The propolis-increased
BNDF expression was completely abolished by preincubation with Wortmannin (200 nM, PI-3K inhibitor), but not by treatment with Y27632 $(1 \mu \mathrm{M}$, ROCK inhibitor $)$ or GFX (200 nM, PKC inhibitor) (Figure 5(c)). BDNF/TrkB signaling has been reported to play an important role in long term potential to further confirm the BDNF signaling to Arc, we use a Carbachol to stimulate SH-SY5Y, and the responses of Carbachol were examined in the presence of U0126 (ERK inhibitors, $10 \mu \mathrm{M}$ ) or ANA-12 (TrkB selective antagonist, $100 \mathrm{nM})$.

$1 \mathrm{~h}$ of treatment with Carbachol can significantly increase the protein expression level of Arc. However, pretreatment with U0126 and ANA significantly reduced the Carbacholincreased Arc (Figures 5(d) and 5(e))). Therefore, the 


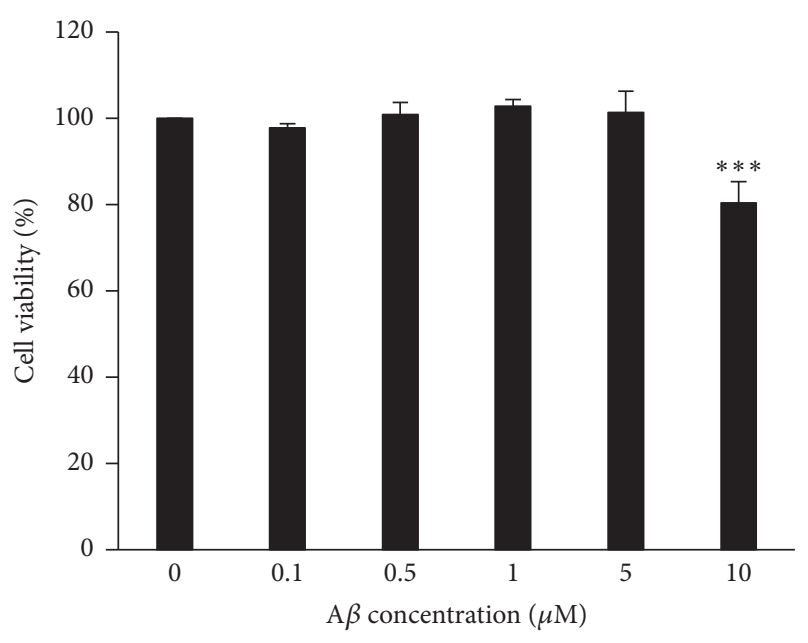

(a)

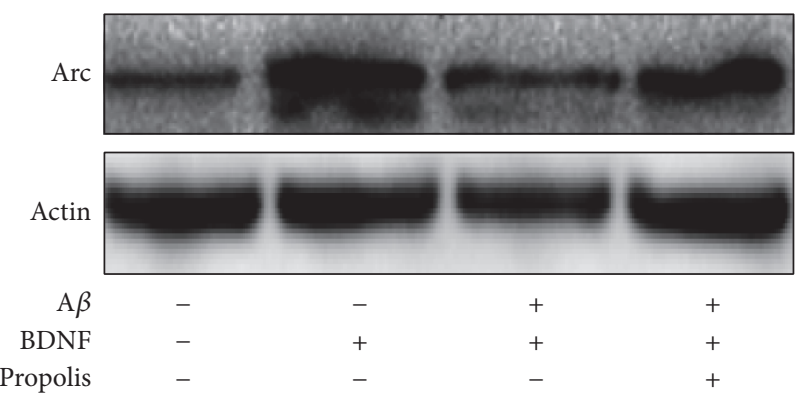

(c)

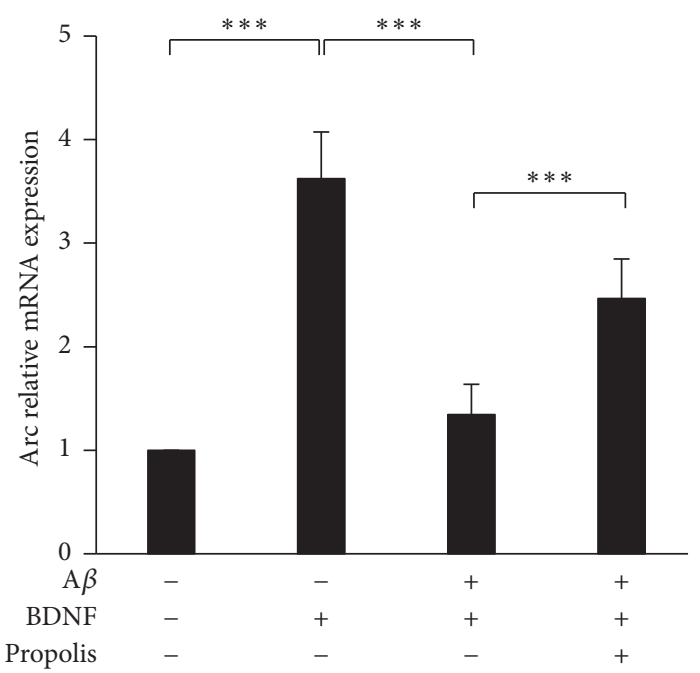

(b)

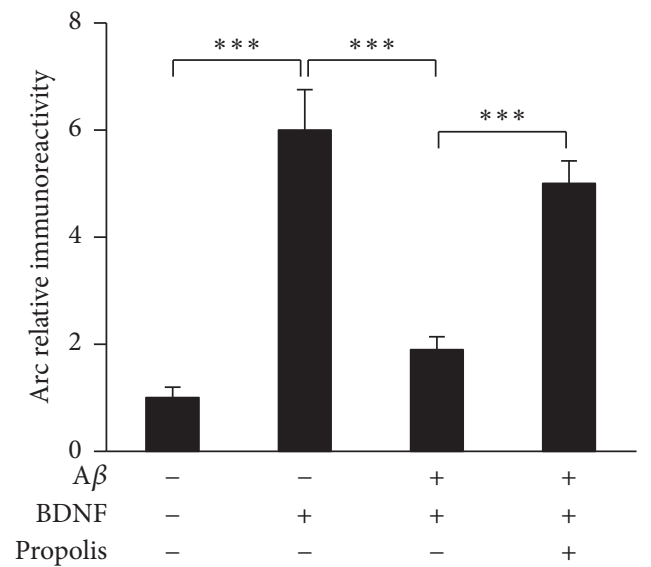

(d)

FIGURE 3: The effect of methanol extracts of propolis on the A $\beta$-induced impairment of BDNF-induced Arc expression in SH-SY5Y cells. (a) SH-SY5Y cells were treated with the indicated concentrations of propolis for $48 \mathrm{~h}$. The cell viability of SH-SY5Y was then measured using a CCK-8 Assay Kit. (b) SH-SY5Y cells were treated with indicated concentrations of $\mathrm{fA} \beta$ for $48 \mathrm{~h}$. The cell viability of SH-SY5Y was then measured again using a CCK-8 Assay Kit. (c) SH-SY5Y cells were pretreated with $\mathrm{fA} \beta(5 \mu \mathrm{M})$ for $6 \mathrm{~h}$, followed by incubation with BDNF $(10 \mathrm{ng} / \mathrm{mL})$ for $2 \mathrm{~h}$. Propolis was treated $2 \mathrm{~h}$ before BDNF application. (d) The expression of Arc after treatment with fA $\beta$, propolis, or BDNF. (d) The quantitative analysis of Arc protein expression. The results are expressed as the mean \pm SEM $(n=4$ each), and the asterisks indicate a statistically significant difference from the indicated group value $\left({ }^{* * *} p<0.001\right)$.

BDNF/TrkB/ERK may regulate the Arc in SH-SY5Y. These observations demonstrate that propolis upregulates BNDF expression through PI-3K-dependent pathways.

3.6. Effect of Propolis on Arc Expression in SH-SY5Y Cells. We further examined the effects of propolis on Arc expression in SH-SY5Y cells. Arc expression is very low in untreated SH-SY5Y cells. Surprisingly, even low-level $(0.5 \mu \mathrm{g} / \mathrm{mL})$ pretreatment with propolis for $30 \mathrm{~min}$ significantly increased the Arc mRNA expression in SH-SY5Y cells in a dose-dependent manner. The safety dose of propolis $(5 \mu \mathrm{g} / \mathrm{mL}$ and $10 \mu \mathrm{g} / \mathrm{mL})$ induced Arc mRNA expression 13- and 16-fold found in untreated cultured cells (Figure 6(a)). We further investigated the time-dependent regulation of propolis $(10 \mu \mathrm{g} / \mathrm{mL})$ on Arc expression. Arc mRNA expression is significantly increased as early as $10 \mathrm{~min}$ after treatment, peaking at $30 \mathrm{~min}$ after, lasting for $60 \mathrm{~min}$, and eventually recovering to the untreated level (the basal levels) at $120 \mathrm{~min}$ after propolis treatment (Figure 6(b)). Our data indicated that the Arc mRNA expression-inducing effects of $10 \mu \mathrm{g} / \mathrm{mL}$ propolis treatment peaked at $30 \mathrm{~min}$; therefore, this concentration and time point were chosen for subsequent experiments.

We finally analyzed the signaling pathways of the effects of propolis on Arc induction. Pretreatment with Wortmannin $(200 \mathrm{nM})$ completely abolished the propolis-induced Arc expression in SH-SY5Y cells; however, Y27632 $(1 \mu \mathrm{M})$ or GFX (200 nM) did not reduce the expression (Figure 6(c)). Furthermore, propolis $(10 \mu \mathrm{g} / \mathrm{mL})$ for $60 \mathrm{~min}$ significantly increased the Arc protein expression, and the propolisincreased Arc protein expression was significantly reduced 


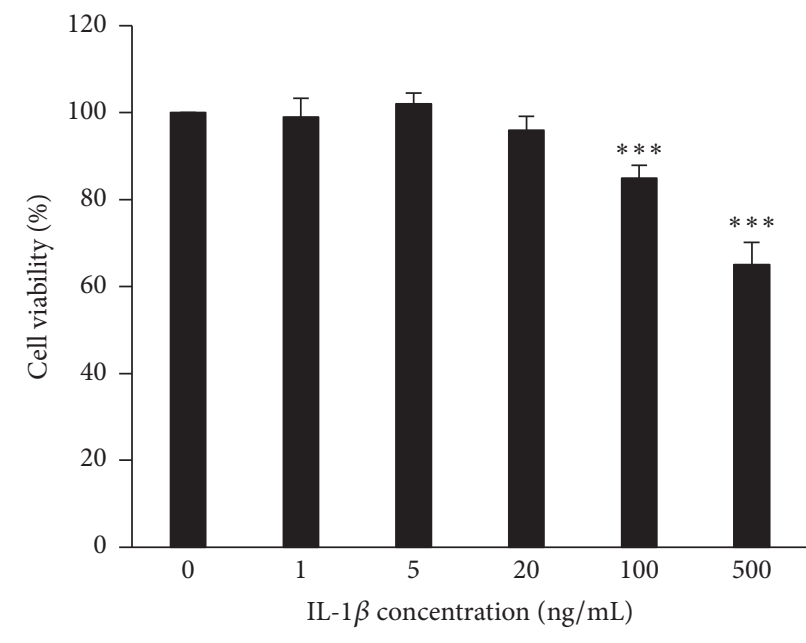

(a)

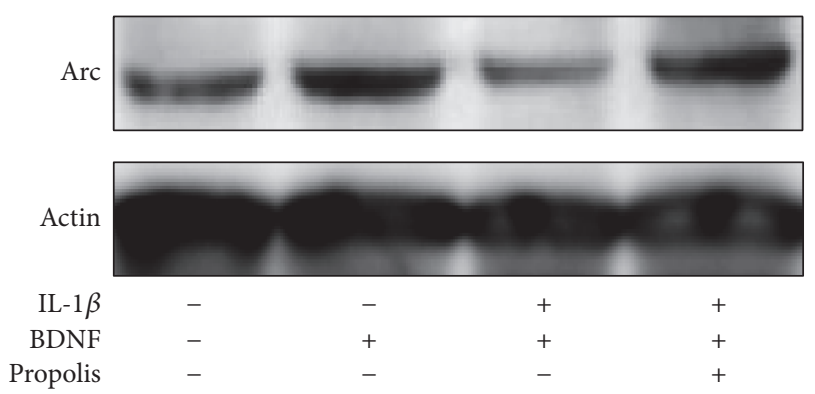

(c)

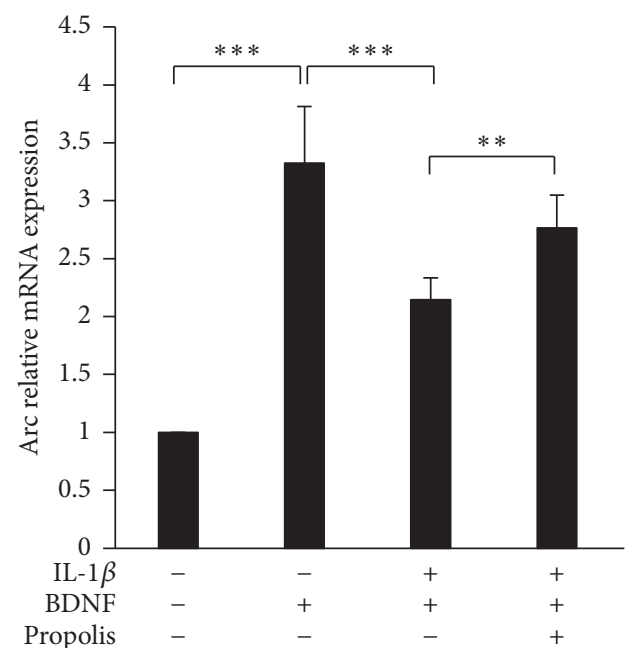

(b)

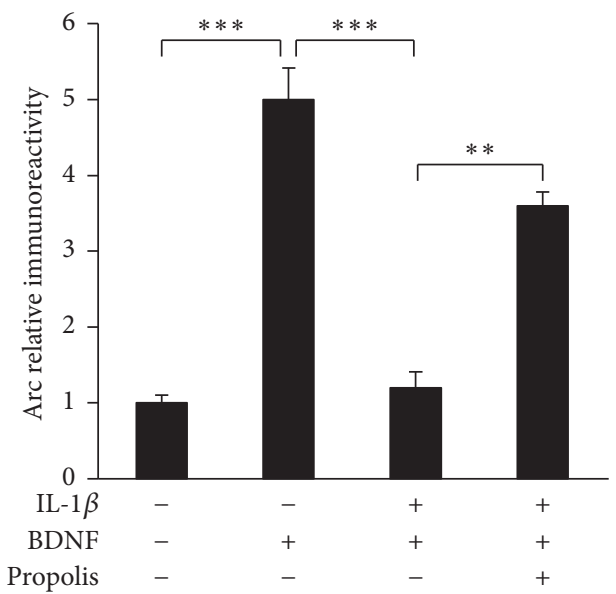

(d)

FIGURE 4: The effect of methanol extracts of propolis on the IL-1 $\beta$-induced impairment of BDNF-induced Arc expression in SH-SY5Y cells. (a) SH-SY5Y cells were treated with the indicated concentrations of IL-1 $\beta$ for $48 \mathrm{~h}$. The cell viability of SH-SY5Y was then measured using a CCK-8 Assay Kit. (b) SH-SY5Y cells were pretreated with IL-1 $\beta(20 \mathrm{ng} / \mathrm{mL})$ for $6 \mathrm{~h}$ followed by incubation with BDNF (10 ng/mL) for $2 \mathrm{~h}$. Propolis was treated $2 \mathrm{~h}$ before BDNF application. (c) The expression of Arc after treatment with IL-1 $\beta$, propolis, or BDNF. (d) The quantitative analysis of Arc protein expression. The results are expressed as the mean $\pm \operatorname{SEM}(n=4$ each), and the asterisks indicate a statistically significant difference from the indicated group value $\left({ }^{* *} p<0.01,{ }^{* * *} p<0.001\right)$.

by Wortmannin, but not by Y27632 or GFX (Figures 6(c) and 6(d)). These data indicate that propolis acts through PI$3 \mathrm{~K}$-dependent pathways for enhancing Arc transcription and protein production.

Artepillin C, a polyphenol with a molecular weight of 300.4 extracted from Brazilian green propolis, has been reported to have the effect on neurite outgrowth of PC12 cells and the signaling pathways involved [33]. Therefore, we also analyzed the effects of Artepillin $\mathrm{C}$ on the expression level of Arc in SH-SY5Y cells. We found that Artepillin $\mathrm{C}$ significantly increased the protein expression of Arc in SH-SY5Y cells; however, the Artepillin-increased Arc was significantly reduced by pretreatment with Wortmannin. The response of Artepillin C in SH-SY5Y cells was consistent with treatment with propolis. Therefore, Artepillin $\mathrm{C}$ may be one of the functional components of propolis that acts through
PI-3K-dependent pathways for enhancing Arc transcription and protein production.

\section{Discussion}

The major findings of the present study are that Brazilian green propolis decreases the oxidative stress but increases the neurodegenerative dysregulated factors of synapse efficacy in human neuronal SH-SY5Y cells (summarized in Figure 7). To our knowledge, this is the first report to explore the directly neuroprotective effects of propolis on neurodegenerative damage.

Oxidative stress is a major harmful component to induce neurodegenerative damage in $\mathrm{AD}[3,4]$, because oxidative stress with overproduction of ROS causes damage to the cellular components, including DNA, resulting in subsequent 


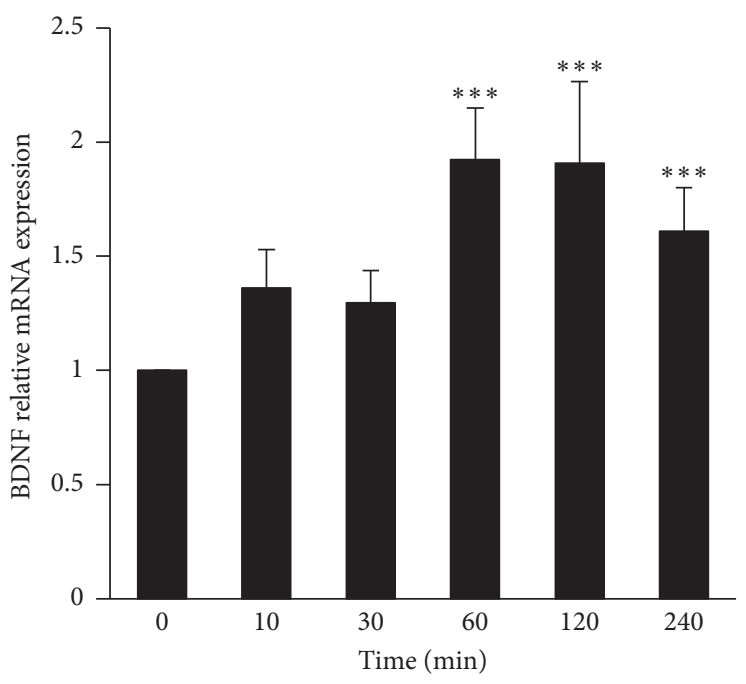

(a)

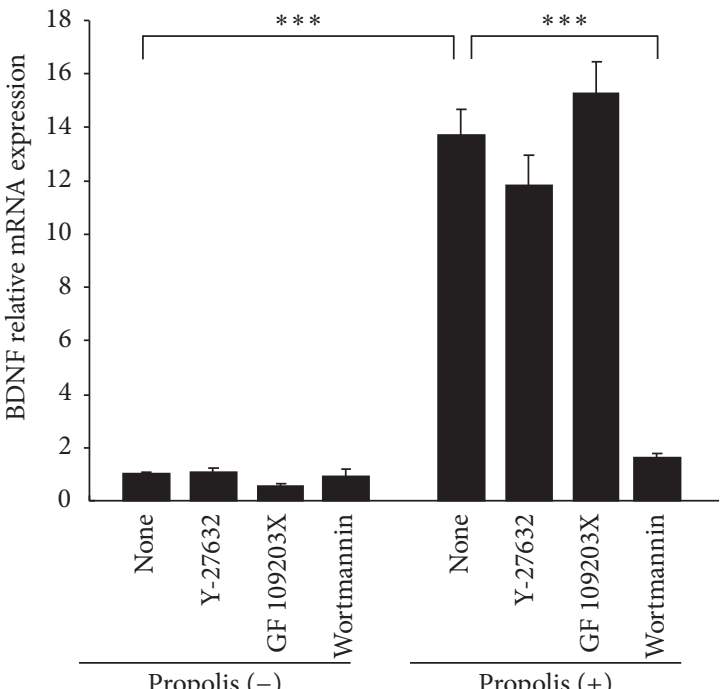

(c)

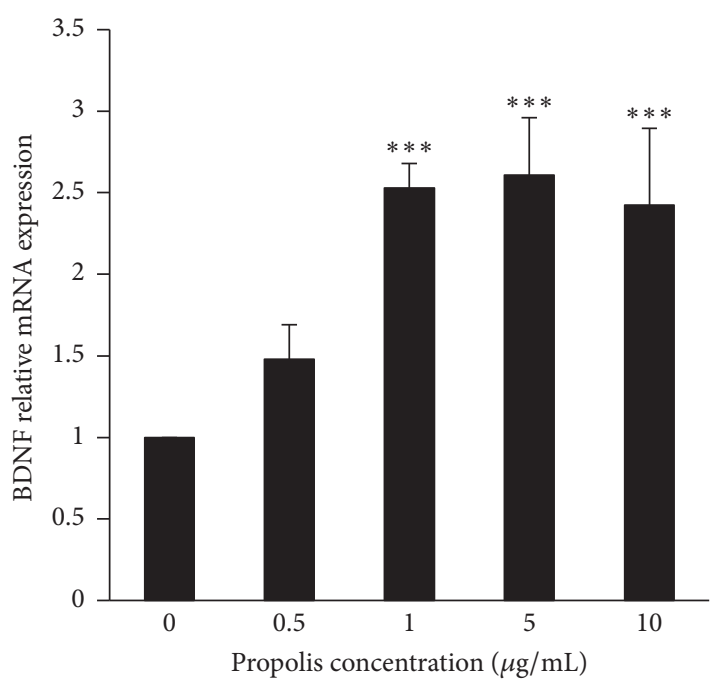

(b)
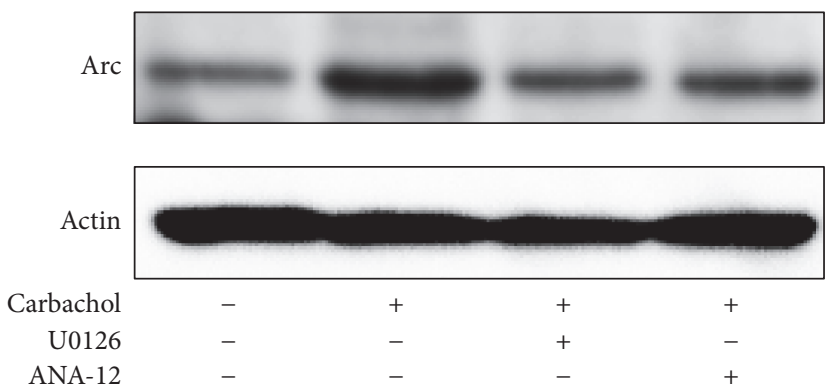

(d)

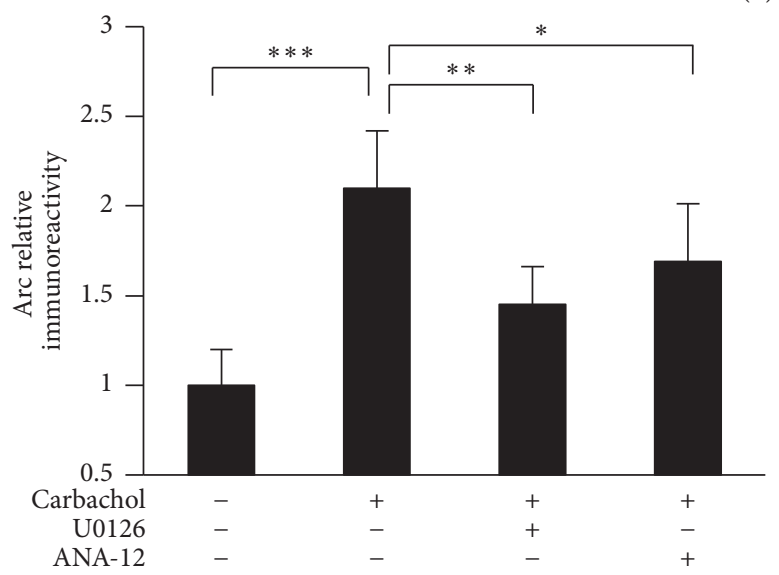

(e)

FIGURE 5: The effect of methanol extracts of propolis on BDNF expression in SH-SY5Y cells. (a) Time-dependent effects of $10 \mu \mathrm{g} / \mathrm{mL}$ propolis on BDNF mRNA expression in SH-SY5Y cells. (b) Dose-dependent effects of propolis on Arc mRNA expression in SH-SY5Y cells at 60 min after incubation. (c) Effects of specific inhibitors on BDNF mRNA expression. GF109203X hydrochloride (protein kinase C inhibitor, $200 \mu \mathrm{M}$ ), Y-27632 dihydrochloride (Rho-associated protein kinase inhibitor, $1 \mu \mathrm{M}$ ), and Wortmannin (phosphoinositide 3-kinase inhibitor, 200 nM) were pretreated for $1 \mathrm{~h}$, followed by incubation with $10 \mu \mathrm{g} / \mathrm{mL}$ propolis for $30 \mathrm{~min}$. (d) The expression of Arc after treatment with Carbachol $(1 \mathrm{mM})$ and pretreatment with U0126 (ERK inhibitors, $10 \mu \mathrm{M}$ ) or ANA-12 (TrkB selective antagonist, $100 \mathrm{nM}$ ). (e) The quantitative analysis of Arc protein expression shown in (d). The results are expressed as the mean \pm SEM $(n=4$ each), and the asterisks indicate a statistically significant difference from the indicated value $\left({ }^{*} p<0.01,{ }^{* *} p<0.005\right.$, and $\left.{ }^{* * *} p<0.001\right)$. 


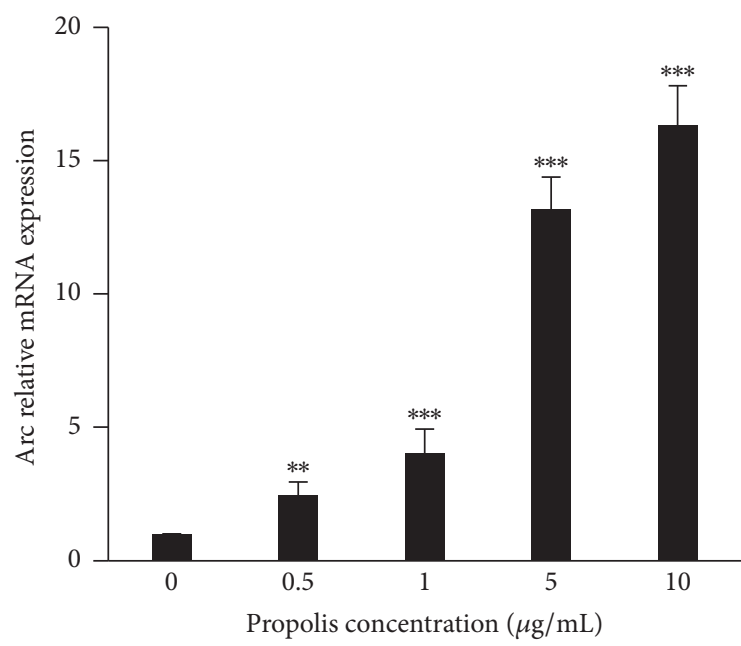

(a)

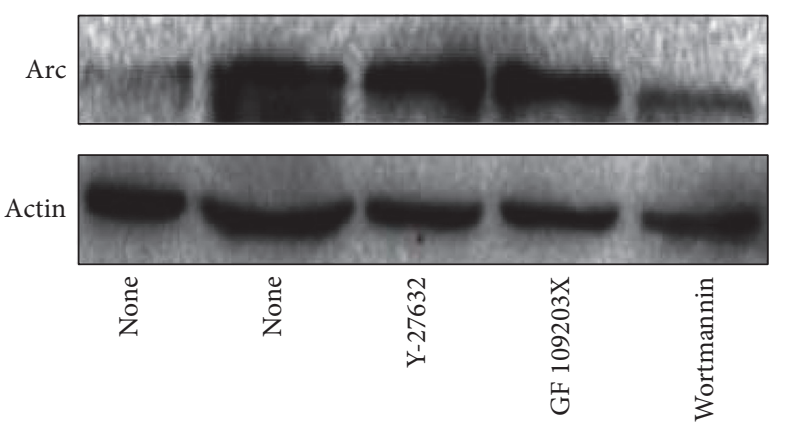

Propolis (+)

(c)

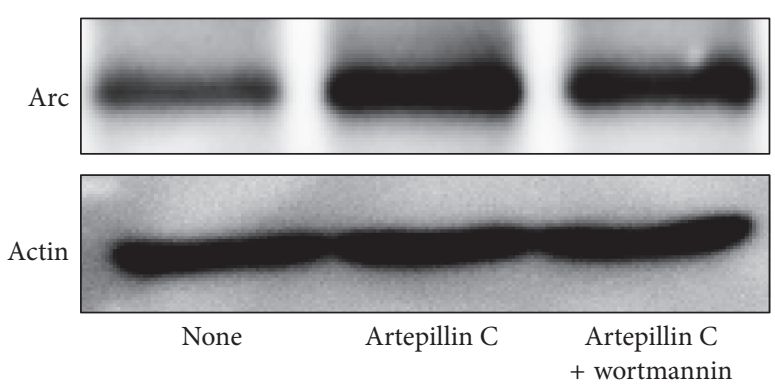

(e)

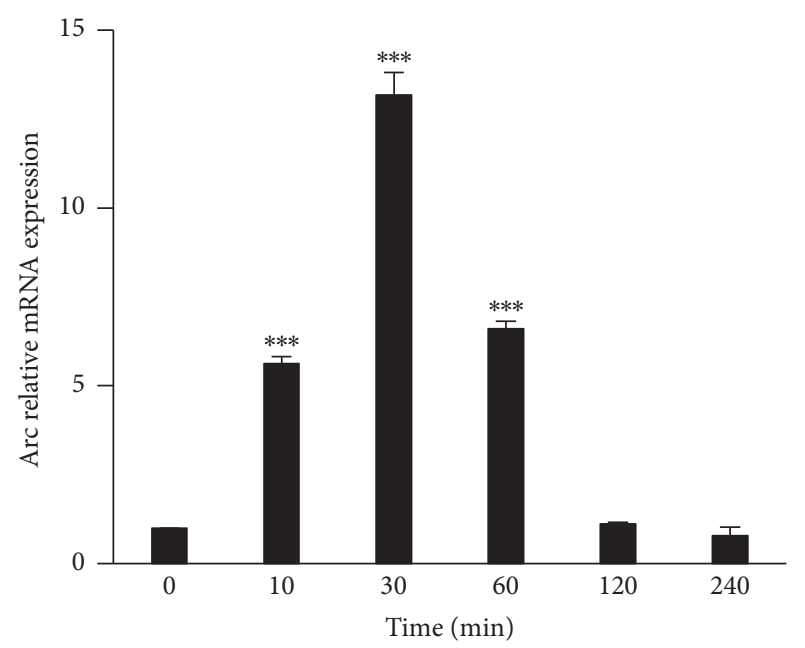

(b)

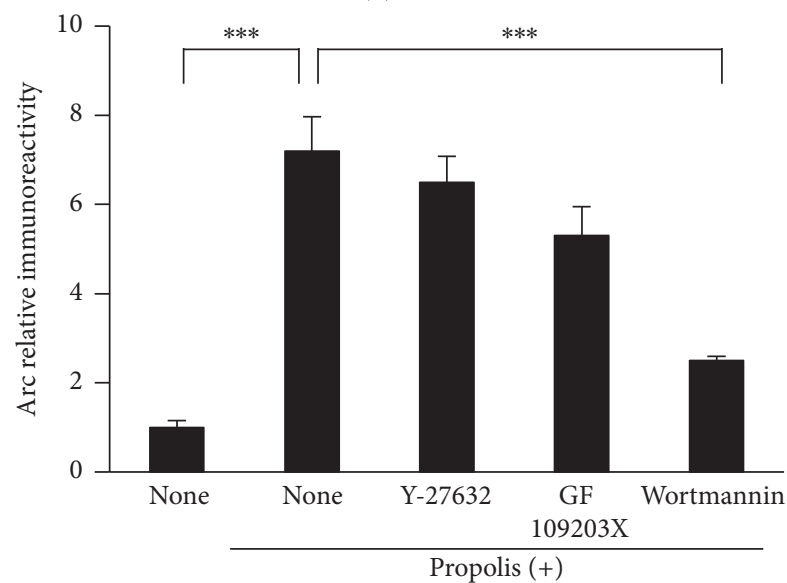

(d)

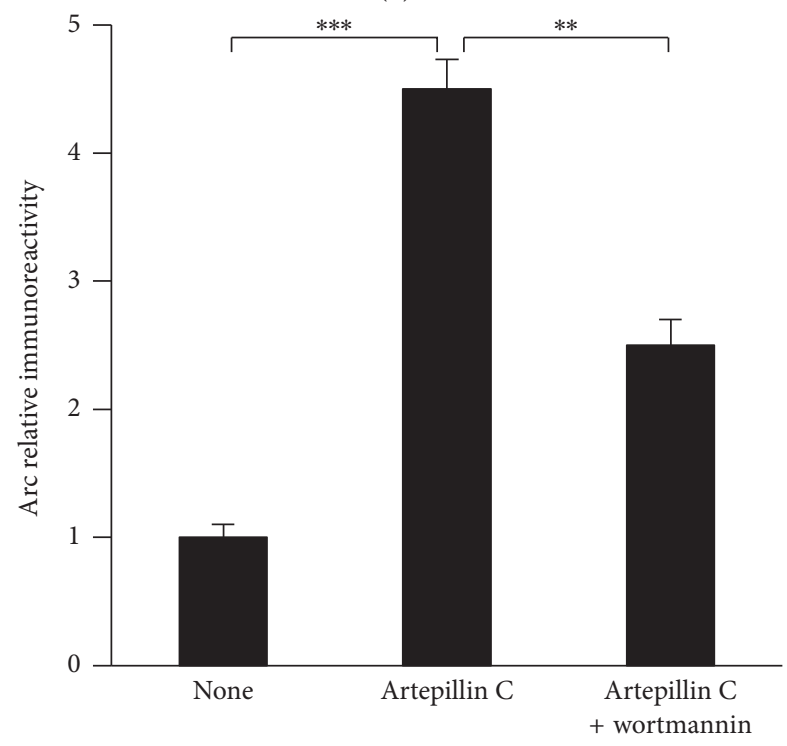

(f)

FIGURE 6: Effect of methanol extracts of propolis on Arc expression in SH-SY5Y cells. (a) Dose-dependent effects of propolis on Arc mRNA expression in SH-SY5Y cells at $30 \mathrm{~min}$ after incubation. (b) Time-dependent effects of $10 \mu \mathrm{g} / \mathrm{mL}$ propolis on Arc mRNA expression in SHSY5Y cells. (c) Effects of specific inhibitors on Arc protein expression. GF109203X hydrochloride (protein kinase C inhibitor, $200 \mu \mathrm{M}$ ), Y27632 dihydrochloride (Rho-associated protein kinase inhibitor, $1 \mu \mathrm{M}$ ), and Wortmannin (phosphoinositide 3-kinase inhibitor, $200 \mathrm{nM}$ ) were pretreated for $1 \mathrm{~h}$, followed by incubation with $10 \mu \mathrm{g} / \mathrm{mL}$ propolis for $30 \mathrm{~min}$. (d) The quantitative analyses of Arc protein expression. (e) The expression of Arc after treatment with Artepillin C $(20 \mu \mathrm{M})$ and pretreatment with Wortmannin. (f) The quantitative analysis of Arc protein expression shown in (e). The results are expressed as the mean \pm SEM $(n=4$ each), and the asterisks indicate a statistically significant difference from the control value or propolis-treated group $\left({ }^{* *} p<0.005,{ }^{* * *} p<0.001\right)$. 


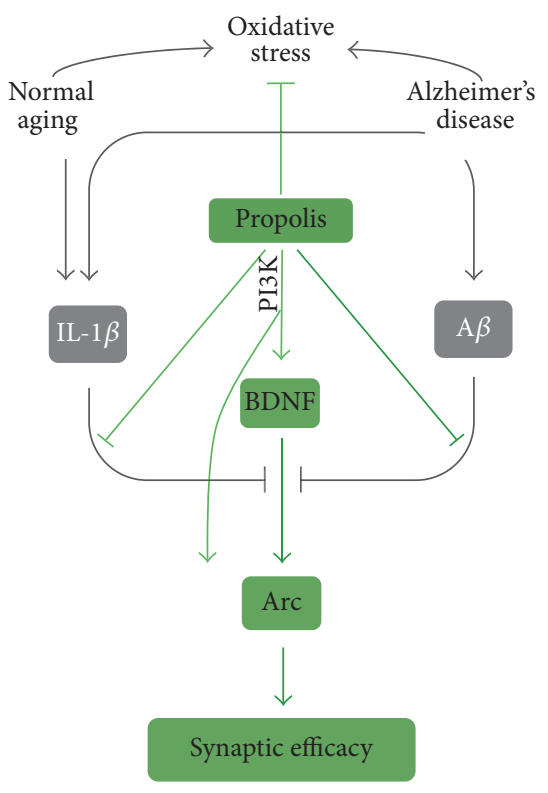

FIGURE 7: A schematic representation of the effects and the principle molecular mechanisms of Brazilian green propolis on neurodegenerative damage-induced oxidative stress and downregulation of synaptic efficacy.

cell death. Antioxidant therapy therefore is considered as an approach in prevention and clinical management of $\mathrm{AD}$ [6]. We used an in vitro model of human neuronal SH-SY5Y cells to investigate the direct effect of Brazilian green propolis (propolis) and its signaling transductions on Arc expression to avoid other effectors. Pretreatment with propolis could protect the $\mathrm{H}_{2} \mathrm{O}_{2}$-induced cell death, which agreed with those of the previous reports showing baccharin, p-Coumaric acid, and Artepillin C; the active components of propolis are effective in reducing neurotoxicity [29-32]. We found that propolis significantly inhibited the $\mathrm{H}_{2} \mathrm{O}_{2}$ induced mitochondria ROS generation as well as nuclear DNA damage in SH-SY5Y cells (Figures 1 and 2). Thus we provide the first evidence that propolis attenuates the oxidative stress-induced DNA damage directly in neuronal cells.

The dysfunction of synaptic efficacy is an early neurodegenerative damage in $\mathrm{AD}[1,21]$, because the impairment of synaptic activation precedes substantial $\mathrm{A} \beta$ accumulation and neuron loss in the brain [10,41,42]. BDNF-induced Arc expression is widely used as a marker of defective synaptic efficacy $[21,26,43]$. In the present study, we found that preexposure to $\mathrm{fA} \beta$ (a neurodegenerative hallmark) at a nonlethal concentration $(5 \mu \mathrm{M})$ impaired BDNF-induced Arc expression (Figure 3(b)); however, fA $\beta$ at a nonlethal concentration did not affect Arc expression in SH-SY5Y cells (data not shown). These data were consistent with the findings of previous studies showing that BDNF-induced Arc expression was inhibited by pretreatment with oligomeric $\mathrm{A} \beta$ or fA $\beta$ in cultured cortical neurons $[21,26,44]$. Surprisingly, treatment with $(10 \mu \mathrm{g} / \mathrm{mL})$ for 120 min significantly reversed the $\mathrm{fA} \beta$-induced impairment of BDNF-induced Arc expression in SH-SY5Y cells. Since a decline in Arc expression is correlated with cognitive impairment in $\mathrm{AD}[45,46]$, BDNFinduced Arc expression fundamentally regulates the synaptic efficacy $[17,18]$. These observations indicate that propolis can prevent the $\mathrm{fA} \beta$-induced dysfunction of synaptic efficacy in neuronal cells.

Increasing evidence indicates that microglia-related neuroinflammation contributes to the decline in cognitive function during aging as well as in $\operatorname{AD}[47,48]$. As a potent activator for exacerbating neuroinflammation, IL-1 $\beta$ has been reported to suppress BDNF-dependent synaptic efficacy, resulting in cognitive impairment [26, 49]. Furthermore, the overexpression of IL- $1 \beta$ in a transgenic mouse model resulted in increased microglia activation with a significant reduction in behaviorally induced Arc levels and impaired contextual and spatial memory [50]. In the present study, we demonstrated that nonlethal concentrations of IL- $1 \beta$ (20 ng/mL) impaired BDNF-induced Arc expression in SHSY5Y cells (Figures $4(\mathrm{~b})-4(\mathrm{~d})$ ), a finding that agreed with those of a previous report showing that IL- $1 \beta$ suppressed the BDNF-induced Arc expression in cultured brain slices [26]. Importantly, treatment with propolis significantly reversed the IL- $1 \beta$-induced impairment of BDNF-induced Arc expression. These observations indicate that propolis can reverse the neuroinflammation-induced dysfunction of synaptic efficacy in neuronal cells.

BDNF, as a neurotropic factor, fundamentally controls the synaptic efficacy $[17,51]$ and closely correlates with cognitive functions $[14,19]$. Indeed, BDNF levels are reduced even in the preclinical stages of $\mathrm{AD}$ [52]. In the present study, treatment with propolis significantly increased the BDNF expression in SH-SY5Y cells in dose- and timedependent manners. Furthermore, the propolis-upregulated BNDF expression was completely abolished by preincubation with PI3K inhibitor, indicating that the effects of propolis on BDNF expression are mediated by the PI3K signaling pathway.

Arc expression was low in the untreated SH-SY5Y cells, which agreed with the findings of other reports using cultured primary cortical neurons $[53,54]$. Exogenous treatment with propolis induced Arc expression in SH-SY5Y cells in both dose- and time-dependent manners. Of note, exposure to propolis induced rapid, robust Arc mRNA expression, as quickly as $10 \mathrm{~min}$ after exposure and peaking at $30 \mathrm{~min}$, which paralleled the Arc expression peaks around $30 \mathrm{~min}$ after behavior induction [55]. Therefore, Arc may serve as an early beginning effector molecule for propolis-induced neuronal activity.

The PI3K signaling pathway plays a pivotal role in synaptic efficacy and memory consolidation [56-58]. The observations, of which the effects of propolis on Arc expression are mediated by the PI-3K signaling pathway, thus provide the underlying mechanism of propolis in directly regulating the molecule for synaptic efficacy in human neuronal cells. Artepillin C, a major component of Brazilian green propolis, has also been found to act as a neurotrophic-like factor for promoting NGF-induced neurite outgrowth [33]. Our ongoing human research at high altitude shows that elderly individuals take propolis score significantly higher on cognitive tests than nontreated individuals (Wu \& Zhu et al., 
unpublished data). The neuroprotective effects of Brazilian green propolis on neurodegenerative damage might provide a valuable therapeutic strategy for prevention of cognitive impairment in $\mathrm{AD}$ as well as aging.

\section{Conclusion}

Brazilian green propolis could reduce oxidative stress and prevent the neurodegenerative damaged synapse efficacy (schematic represented in Figure 7). Therefore, we provide the principle molecular mechanisms of the benefits of propolis as the therapeutic agent for maintenance cognitive function of brain.

\section{Competing Interests}

The authors declare no conflict of interests in association with this study.

\section{Authors' Contributions}

Junjun Ni and Zhou Wu contributed equally to this work.

\section{Acknowledgments}

This work was supported by a Yamada Research Grant to Zhou Wu (N0.0183).

\section{References}

[1] D. J. Selkoe, "Alzheimer's disease is a synaptic failure," Science, vol. 298, no. 5594, pp. 789-791, 2002.

[2] R. Brookmeyer, D. A. Evans, L. Hebert et al., "National estimates of the prevalence of Alzheimer's disease in the United States," Alzheimer's \& Dementia, vol. 7, no. 1, pp. 61-73, 2011.

[3] L. Y. Al-Ayadhi, "Oxidative stress and neurodegenerative disease," Neurosciences, vol. 9, no. 1, pp. 19-23, 2004.

[4] N. H. Zawia, D. K. Lahiri, and F. Cardozo-Pelaez, "Epigenetics, oxidative stress, and Alzheimer disease," Free Radical Biology and Medicine, vol. 46, no. 9, pp. 1241-1249, 2009.

[5] H.-U. Simon, A. Haj-Yehia, and F. Levi-Schaffer, "Role of reactive oxygen species (ROS) in apoptosis induction," Apoptosis, vol. 5, no. 5, pp. 415-418, 2000.

[6] M. Manczak, P. Mao, M. J. Calkins et al., "Mitochondriatargeted antioxidants protect against amyloid- $\beta$ toxicity in Alzheimer's disease neurons," Journal of Alzheimer's Disease, vol. 20, S2, pp. S609-S631, 2010.

[7] H. Akiyama, T. Arai, H. Kondo, E. Tanno, C. Haga, and K. Ikeda, "Cell mediators of inflammation in the Alzheimer disease brain," Alzheimer Disease and Associated Disorders, vol. 14, supplement 1, pp. S47-S53, 2000.

[8] E. G. McGeer and P. L. McGeer, "The importance of inflammatory mechanisms in Alzheimer disease," Experimental Gerontology, vol. 33, no. 5, pp. 371-378, 1998.

[9] E. M. Blalock, K.-C. Chen, K. Sharrow et al., "Gene microarrays in hippocampal aging: statistical profiling identifies novel processes correlated with cognitive impairment," Journal of Neuroscience, vol. 23, no. 9, pp. 3807-3819, 2003.

[10] C. A. Dickey, J. F. Loring, J. Montgomery, M. N. Gordon, P. S. Eastman, and D. Morgan, "Selectively reduced expression of synaptic plasticity-related genes in amyloid precursor protein plus presenilin-1 transgenic mice," Journal of Neuroscience, vol. 23, no. 12, pp. 5219-5226, 2003.

[11] S. Rosi, "Neuroinflammation and the plasticity-related immediate-early gene Arc," Brain, Behavior, and Immunity, vol. 25, no. 1, pp. S39-S49, 2011.

[12] D. F. Swaab and A.-M. Bao, "(Re-)activation of neurons in aging and dementia: lessons from the hypothalamus," Experimental Gerontology, vol. 46, no. 2-3, pp. 178-184, 2011.

[13] G. K. Gouras, D. Tampellini, R. H. Takahashi, and E. CapetilloZarate, "Intraneuronal $\beta$-amyloid accumulation and synapse pathology in Alzheimer's disease," Acta Neuropathologica, vol. 119 , no. 5, pp. 523-541, 2010.

[14] J. F. Guzowski, G. L. Lyford, G. D. Stevenson et al., "Inhibition of activity-dependent arc protein expression in the rat hippocampus impairs the maintenance of long-term potentiation and the consolidation of long-term memory," Journal of Neuroscience, vol. 20, no. 11, pp. 3993-4001, 2000.

[15] J. J. Rodriguez, H. A. Davies, A. T. Silva et al., "Long-term potentiation in the rat dentate gyrus is associated with enhanced Arc/Arg3.1 protein expression in spines, dendrites and glia," European Journal of Neuroscience, vol. 21, no. 9, pp. 2384-2396, 2005.

[16] O. Steward and P. Worley, "Local synthesis of proteins at synaptic sites on dendrites: role in synaptic plasticity and memory consolidation?" Neurobiology of Learning and Memory, vol. 78, no. 3, pp. 508-527, 2002.

[17] C. R. Bramham and E. Messaoudi, "BDNF function in adult synaptic plasticity: the synaptic consolidation hypothesis," Progress in Neurobiology, vol. 76, no. 2, pp. 99-125, 2005.

[18] S.-W. Ying, M. Futter, K. Rosenblum et al., "Brain-derived neurotrophic factor induces long-term potentiation in intact adult hippocampus: requirement for ERK activation coupled to CREB and upregulation of Arc synthesis," Journal of Neuroscience, vol. 22, no. 5, pp. 1532-1540, 2002.

[19] J. F. Guzowski, B. L. McNaughton, C. A. Barnes, and P. F. Worley, "Environment-specific expression of the immediate-early gene Arc in hippocampal neuronal ensembles," Nature Neuroscience, vol. 2, no. 12, pp. 1120-1124, 1999.

[20] E. Messaoudi, S.-W. Ying, T. Kanhema, S. D. Croll, and C. R. Bramham, "Brain-derived neurotrophic factor triggers transcription-dependent, late phase long-term potentiation in vivo," Journal of Neuroscience, vol. 22, no. 17, pp. 7453-7461, 2002.

[21] D.-C. Wang, S.-S. Chen, Y.-C. Lee, and T.-J. Chen, "Amyloid- $\beta$ at sublethal level impairs BDNF-induced arc expression in cortical neurons," Neuroscience Letters, vol. 398, no. 1-2, pp. 78-82, 2006.

[22] M. V. Chao, R. Rajagopal, and F. S. Lee, "Neurotrophin signalling in health and disease," Clinical Science, vol. 110, no. 2, pp. 167-173, 2006.

[23] H. Akiyama, “Inflammation and Alzheimer's disease," Neurobiology of Aging, vol. 21, no. 3, pp. 383-421, 2000.

[24] M. T. Heneka, M. K. O’Banion, D. Terwel, and M. P. Kummer, "Neuroinflammatory processes in Alzheimer's disease," Journal of Neural Transmission, vol. 117, no. 8, pp. 919-947, 2010.

[25] P. L. McGeer, J. Rogers, and E. G. McGeer, "Inflammation, antiinflammatory agents and Alzheimer disease: the last 12 years," Journal of Alzheimer's Disease, vol. 9, no. 3, pp. 271-276, 2006.

[26] L. Tong, G. A. Prieto, E. A. Kramár et al., "Brain-derived neurotrophic factor-dependent synaptic plasticity is suppressed by interleukin- $1 \beta$ via $\mathrm{p} 38$ mitogen-activated protein kinase," Journal of Neuroscience, vol. 32, no. 49, pp. 17714-17724, 2012. 
[27] V. S. Bankova, S. L. de Castro, and M. C. Marcucci, "Propolis: recent advances in chemistry and plant origin," Apidologie, vol. 31, no. 1, pp. 3-15, 2000.

[28] M. Marcucci, "Propolis: chemical composition, biological properties and therapeutic activity," Apidologie, vol. 26, no. 2, pp. 8399, 1995.

[29] J.-H. Yoon, K. Youn, C.-T. Ho, M. V. Karwe, W.-S. Jeong, and M. Jun, " $p$-coumaric acid and ursolic acid from Corni fructus attenuated $\beta$-amyloid ${ }_{25--35}$-induced toxicity through regulation of the NF- $\kappa \mathrm{B}$ signaling pathway in PC12 cells," Journal of Agricultural and Food Chemistry, vol. 62, no. 21, pp. 4911-4916, 2014.

[30] M. O. Villareal, K. Sasaki, D. Margout et al., "Neuroprotective effect of Picholine virgin olive oil and its hydroxycinnamic acids component against $\beta$-amyloid-induced toxicity in SHSY5Y neurotypic cells," Cytotechnology, vol. 68, no. 6, pp. 25672578, 2016.

[31] Y. Nakajima, M. Shimazawa, S. Mishima, and H. Hara, "Neuroprotective effects of Brazilian green propolis and its main constituents against oxygen-glucose deprivation stress, with a gene-expression analysis," Phytotherapy Research, vol. 23, no. 10, pp. 1431-1438, 2009.

[32] Y. Nakajima, M. Shimazawa, S. Mishima, and H. Hara, "Water extract of propolis and its main constituents, caffeoylquinic acid derivatives, exert neuroprotective effects via antioxidant actions," Life Sciences, vol. 80, no. 4, pp. 370-377, 2007.

[33] Y. Kano, N. Horie, S. Doi et al., "Artepillin C derived from propolis induces neurite outgrowth in PC12m3 cells via ERK and p38 MAPK pathways," Neurochemical Research, vol. 33, no. 9, pp. 1795-1803, 2008.

[34] Y. Liu, Z. Wu, X. Zhang et al., "Leptomeningeal cells transduce peripheral macrophages inflammatory signal to microglia in reponse to Porphyromonas gingivalis LPS," Mediators of Inflammation, vol. 2013, Article ID 407562, 11 pages, 2013.

[35] Z. Wu, L. Sun, S. Hashioka et al., "Differential pathways for interleukin- $1 \beta$ production activated by chromogranin $\mathrm{A}$ and amyloid $\beta$ in microglia," Neurobiology of Aging, vol. 34, no. 12, pp. 2715-2725, 2013.

[36] D. Uberti, L. Piccioni, A. Colzi, D. Bravi, P. L. Canonico, and M. Memo, "Pergolide protects SH-SY5Y cells against neurodegeneration induced by $\mathrm{H}_{2} \mathrm{O}_{2}$," European Journal of Pharmacology, vol. 434, no. 1-2, pp. 17-20, 2002.

[37] Z. Wu, A. Zhu, F. Takayama et al., "Brazilian green propolis suppresses the hypoxia-induced neuroinflammatory responses by inhibiting NF- $\kappa \mathrm{B}$ activation in microglia," Oxidative Medicine and Cellular Longevity, vol. 2013, Article ID 906726, 10 pages, 2013.

[38] J. Ni, Z. Wu, C. Peterts, K. Yamamoto, H. Qing, and H. Nakanishi, "The critical role of proteolytic relay through cathepsins B and $\mathrm{E}$ in the phenotypic change of microglia/macrophage," The Journal of Neuroscience, vol. 35, no. 36, pp. 12488-12501, 2015.

[39] J. Choi, M. C. Sullards, J. A. Olzmann et al., "Oxidative damage of DJ-1 is linked to sporadic Parkinson and Alzheimer diseases," Journal of Biological Chemistry, vol. 281, no. 16, pp. 10816-10824, 2006.

[40] E. W. Englander, Z. Hu, A. Sharma, H.-M. Lee, Z.-H. Wu, and G. H. Greeley, "Rat MYH, a glycosylase for repair of oxidatively damaged DNA, has brain-specific isoforms that localize to neuronal mitochondria," Journal of Neurochemistry, vol. 83, no. 6, pp. 1471-1480, 2002.

[41] C. A. Dickey, M. N. Gordon, J. E. Mason et al., "Amyloid suppresses induction of genes critical for memory consolidation in APP + PS1 transgenic mice," Journal of Neurochemistry, vol. 88, no. 2, pp. 434-442, 2004.

[42] J. J. Palop, J. Chin, N. Bien-Ly et al., "Vulnerability of dentate granule cells to disruption of Arc expression in human amyloid precursor protein transgenic mice," The Journal of Neuroscience, vol. 25, no. 42, pp. 9686-9693, 2005.

[43] T.-J. Chen, D.-C. Wang, and S.-S. Chen, "Amyloid- $\beta$ interrupts the PI3K-Akt-mTOR signaling pathway that could be involved in brain-derived neurotrophic factor-induced Arc expression in rat cortical neurons," Journal of Neuroscience Research, vol. 87, no. 10, pp. 2297-2307, 2009.

[44] V. Echeverria, D. E. Berman, and O. Arancio, "Oligomers of $\beta$-amyloid peptide inhibit BDNF-induced arc expression in cultured cortical neurons," Current Alzheimer Research, vol. 4, no. 5, pp. 518-521, 2007.

[45] B. Monti, C. Berteotti, and A. Constestabile, "Dysregulation of memory-related proteins in the hippocampus of aged rats and their relation with cognitive impairment," Hippocampus, vol. 15, no. 8, pp. 1041-1049, 2005.

[46] D. J. Selkoe and D. Schenk, "Alzheimer's disease: molecular understanding predicts amyloid-based therapeutics," Annual Review of Pharmacology and Toxicology, vol. 43, pp. 545-584, 2003.

[47] H. Nakanishi and Z. Wu, "Microglia-aging: roles of microglial lysosome- and mitochondria-derived reactive oxygen species in brain aging," Behavioural Brain Research, vol. 201, no. 1, pp. 1-7, 2009.

[48] Z. Wu and H. Nakanishi, "Connection between periodontitis and Alzheimer's disease: possible roles of microglia and leptomeningeal cells," Journal of Pharmacological Sciences, vol. 126, no. 1, pp. 8-13, 2014.

[49] C. R. Pugh, M. Fleshner, L. R. Watkins, S. F. Maier, and J. W. Rudy, "The immune system and memory consolidation: a role for the cytokine IL-1 $\beta$," Neuroscience and Biobehavioral Reviews, vol. 25, no. 1, pp. 29-41, 2001.

[50] A. M. Hein, M. R. Stasko, S. B. Matousek et al., "Sustained hippocampal IL-1 $\beta$ overexpression impairs contextual and spatial memory in transgenic mice," Brain, Behavior, and Immunity, vol. 24, no. 2, pp. 243-253, 2010.

[51] Y. Yin, G. M. Edelman, and P. W. Vanderklish, "The brainderived neurotrophic factor enhances synthesis of Arc in synaptoneurosomes," Proceedings of the National Academy of Sciences of the United States of America, vol. 99, no. 4, pp. 23682373, 2002.

[52] S. Peng, J. Wuu, E. J. Mufson, and M. Fahnestock, "Precursor form of brain-derived neurotrophic factor and mature brainderived neurotrophic factor are decreased in the pre-clinical stages of Alzheimer's disease," Journal of Neurochemistry, vol. 93, no. 6, pp. 1412-1421, 2005.

[53] S. Chamniansawat and S. Chongthammakun, "Estrogen stimulates activity-regulated cytoskeleton associated protein (Arc) expression via the MAPK- and PI-3K-dependent pathways in SH-SY5Y cells," Neuroscience Letters, vol. 452, no. 2, pp. 130-135, 2009.

[54] J. Kremerskothen, D. Wendholt, I. Teber, and A. Barnekow, "Insulin-induced expression of the activity-regulated cytoskeletonassociated gene (ARC) in human neuroblastoma cells requires $\mathrm{p} 2 \mathrm{l}$ (ras), mitogen-activated protein kinase/extracellular regulated kinase and src tyrosine kinases but is protein kinase C-independent," Neuroscience Letters, vol. 321, no. 3, pp. 153156, 2002.

[55] V. Ramírez-Amaya, A. Vazdarjanova, D. Mikhael, S. Rosi, P. F. Worley, and C. A. Barnes, "Spatial exploration-induced Arc 
mRNA and protein expression: evidence for selective, networkspecific reactivation," Journal of Neuroscience, vol. 25, no. 7, pp. 1761-1768, 2005.

[56] M. Cammalleri, R. Lütjens, F. Berton et al., "Time-restricted role for dendritic activation of the mTOR-p70 $0^{\mathrm{S} 6 \mathrm{~K}}$ pathway in the induction of late-phase long-term potentiation in the CAl," Proceedings of the National Academy of Sciences of the United States of America, vol. 100, no. 2, pp. 14368-14373, 2003.

[57] J. M. Horwood, F. Dufour, S. Laroche, and S. Davis, "Signalling mechanisms mediated by the phosphoinositide 3-kinase/Akt cascade in synaptic plasticity and memory in the rat," European Journal of Neuroscience, vol. 23, no. 12, pp. 3375-3384, 2006.

[58] P. Opazo, A. M. Watabe, S. G. N. Grant, and T. J. O’Dell, "Phosphatidylinositol 3-kinase regulates the induction of longterm potentiation through extracellular signal-related kinaseindependent mechanisms," The Journal of Neuroscience, vol. 23, no. 9, pp. 3679-3688, 2003. 


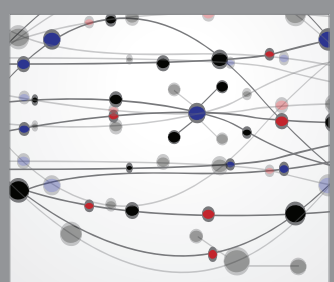

The Scientific World Journal
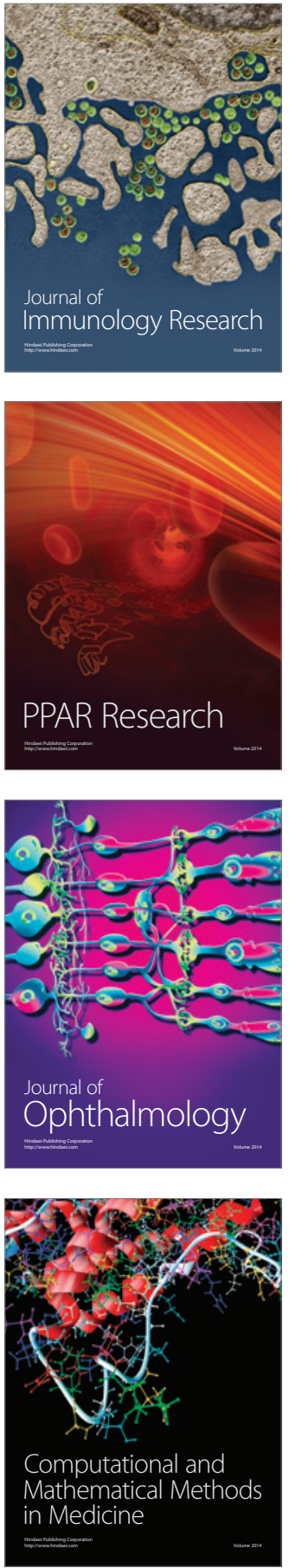

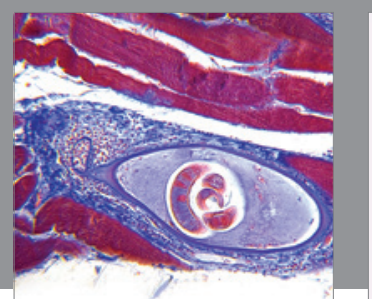

Gastroenterology Research and Practice
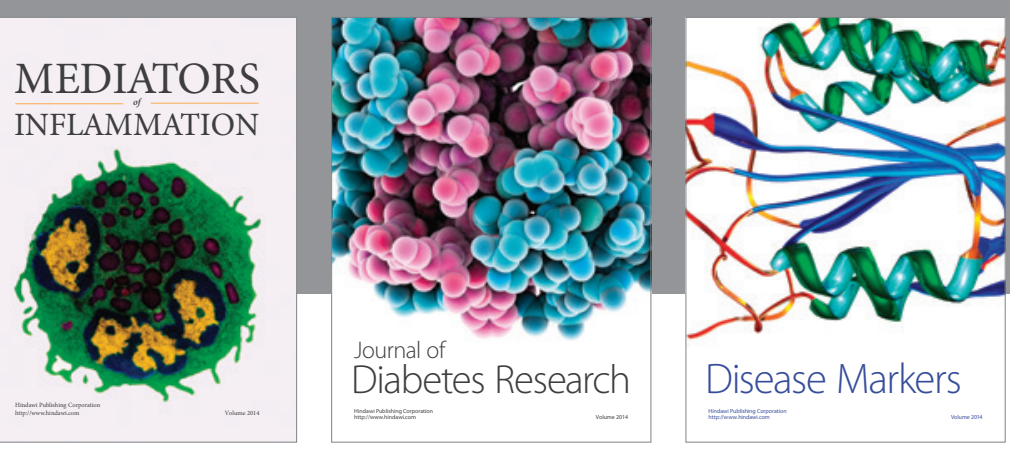

Disease Markers

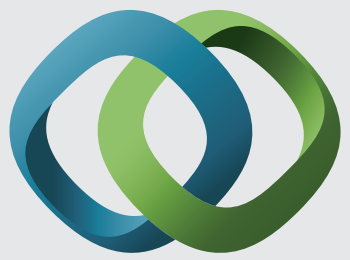

\section{Hindawi}

Submit your manuscripts at

https://www.hindawi.com
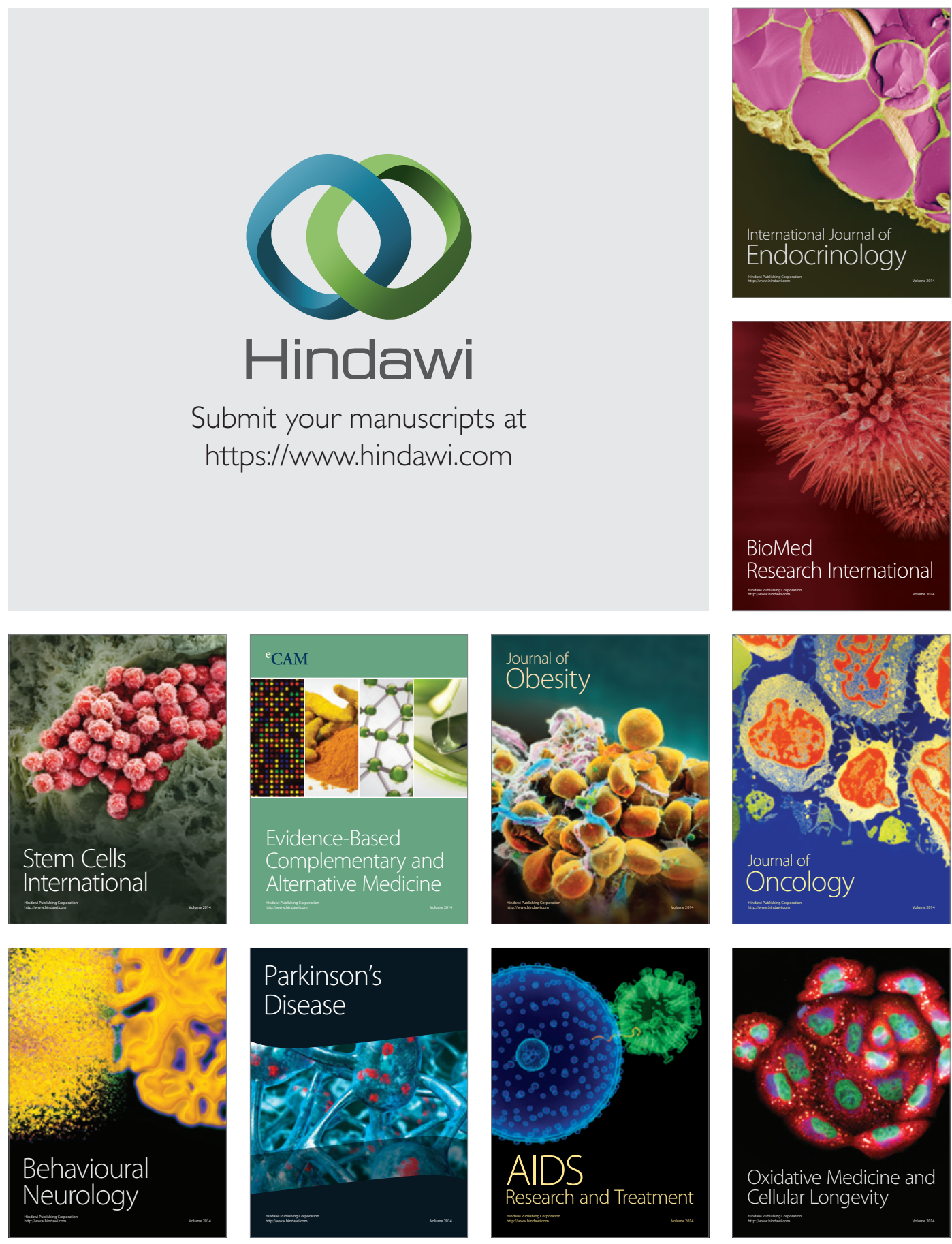